\title{
$1 \operatorname{lin}^{2}$ \\ NRL REPORT \\ NRL - 1952 (11 June) - VIV \\ THE VELOCITY OF SOUND IN SEA WATER AT ZERO DEPTH
}

\author{
V. A. Del Grosso \\ Propagation Branch \\ Sound Division
}

June 11, 1952

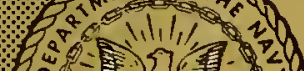

3.

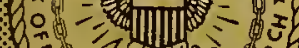

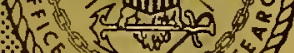

Li NAVAL \&

NAVAL RESEARCH LABORATORY

WASHINGTON, D.C.

GC

1

R4

12402 


\begin{abstract}
The velocity of sound has been measured in natural sea water samples at megacycle frequencies by means of modern interferometric techniques. From these measurements, an empirical equation has been formulated, and new tables and graphs of the velocity of sound in natural sea water at "zero" depth are presented on the basis of this equation.

The validity of utilizing these velocity tables at sonar frequencies is based on theoretical work which indicates the error introduced by so doing is at least an order of magnitude smaller than the claimed accuracy. The accuracy of these tables is estimated to be within \pm 0.2 meter per second. The velocity values range approximately 2-4 meters per second higher than those in existing tables.
\end{abstract}

\title{
PROBLEM STATUS
}

This is an interim report; work on the general project is continuing.

\section{AUTHORIZATION}

NRL Problem S02-04

RDB Project NR 522-040

Manuscript submitted May 15, 1952 
CONTENTS

$\begin{array}{lr}\text { INTRODUCTION } & 1 \\ \text { BACKGROUND } & 1 \\ \text { EXPERIMENTAL PROCEDURE } & 1 \\ \text { RESULTS AND DISCUSSION } & 2 \\ \text { THE CONCEPT OF SALINITY } & 3 \\ \text { VALIDITY OF THESE MEASUREMENTS } & 4 \\ \text { AT SONAR FREQUENCIES } & 4 \\ \text { ACKNOWLEDGMENTS } & 5 \\ \text { REFERENCES } & 6 \\ \text { TABLES AND FIGURES } & \end{array}$

1

1

1

2

3

4

4

5

6 


\section{THE VELOCITY OF SOUND \\ IN SEA WATER AT ZERO DEPTH}

\section{INTRODUCTION}

An accurate knowledge of the velocity of sound in sea water as a function of temperature, chemical composition (salinity and dissolved gas content), and pressure (depth) is essential to sonar-not only for ranging determinations but for calculation of possible refraction which may operate either to channel the sound energy or to send this energy into the ocean depths.

Availab?e tables for the calculation of sound velocity in the ocean are based either on theoretical computations or radio-acoustic ranging (1-5). These latter field measurements, however, assume the existence of homogeneous water between two distant points. The theoretical tables use compressibility and density determinations made over forty years ago and assume the temperature dependence of specific heat for distilled water to be the same as for sea water.

Kuwahara's tables (3), calculated from empirical formulas for the compressibility of sea water, are as accurate as any, and are generally used in this country. These tables have been graphically presented (6), and used by the Naval Research Laboratory. A comparison of velocity values obtained from various tables is made for "normal" sea water of 35 parts per thousand (ppt or $\%$ ) salinity in Table 1 . $^{*}$

\section{BACKGROUND}

Preliminary measurements of sound velocity in sea water with a less accurate instrument (7) (i.e., $\pm 1 \mathrm{~m} / \mathrm{sec}$ ) indicated that Kuwahara's tables yield velocities that are too low by $3-4 \mathrm{~m} / \mathrm{sec}$. The Revised British Admirality Tables (4) yield velocities slightly lower than Kuwahara's. Kuwahara claims an accuracy of $3 \mathrm{~m} / \mathrm{sec}$ for his tables, but the preliminary evidence seemed to indicate that his error is systematic and that his values are consistently low. More information was desired to check the need for revision of sound velocity tables.

The ultrasonic interferometers in present use at the Naval Research Laboratory, capable of measuring the velocity of sound in liquids to a precision of 1 part in 10,000, were chosen as ideal instruments for checking the existing tables.

\section{EXPERIMENTAL PROCEDURE}

Samples of sea water were obtained from the Bermuda-isey West area by various field parties from the Sound Division, NRL. Of the samples received, three were selected

\footnotetext{
* Tables and figures are grouped after the text.
} 
on the basis of clarity and freedom from foreign material. Data concerning these samples will be found in Table 2. The samples were received within one to four days after collection, and their sound velocity was determined with a one-megacycle ultrasonic interferometer as soon as received, and at intervals throughout the investigation. Chlorinities were determined by the Mohr method of $\mathrm{AgNO}_{3}$ titration using a special elongated-scale burette made by the Machlett Company and patterned after a modification of the original Mohr burette suggested by the Woods Hole Oceanographic Institution. Toward the end of this investigation a potentiometric titration with the Beckman automatic titrator and a $\mathrm{Ag}-\mathrm{AgCl}$ electrode in conjunction with a calomel reference electrode was developed. This technique frees the operator from the close control required as the end point is approached, and eliminates the human factor in choosing the relatively difficult to determine colorimetric end point.

The temperature of the interferometer bath was controlled by Magna-Set thermoregulators adjusted to better than $\pm 0.01^{\circ} \mathrm{C}$ by means of a Leeds and Northrup 8160 Platinum Resistance Thermometer in conjunction with an L\&N G-1 Mueller Bridge and an L\&N 2430-A galvanometer. The interferometer cell temperature was determined by Bureau of Standards calibrated mercury-in-glass thermometers which could be estimated to $\pm 0.02^{\circ} \mathrm{C}$.

To obtain various salinities in the range 19-41 parts per thousand, the natural sea water samples were diluted with distilled water and evaporated under vacuum. The chlorinity of each of the solutions was actually determined by Mohr titration in the same manner as the chlorinities of the original samples. The salinities were calculated by the empirical relationship established by an International Commission (8). This relationship is

$$
\text { Salinity }=0.03+1.805 \times \text { Cंhlorinity. }
$$

Sound velocities in the various sea water samples obtained by the above method were determined over a temperature range of $0^{\circ}$ to $40^{\circ} \mathrm{C}$. The measurements were made at a one-megacycle frequency, but several determinations were made at three megacycles.

\section{RESULTS AND DISCUSSION}

The experimental determinations of sea water sound velocity were plotted in two series of graphs (not given here), velocity vs. temperature with salinity parameter and velocity vs. salinity with temperature parameter. The points in the latter graph formed straight lines for individual temperatures. From this graph, velocity values at integral temperatures and salinities were read to \pm 0.1 meter per second. These values were then processed by the method of least squares to yield the following empirical equation for the velocity of sound in sea water over a range of salinities from 19-41 parts per thousand and a range of temperatures from $0^{\circ}$ to $40^{\circ} \mathrm{C}$.

$$
\begin{aligned}
V_{m}= & 1448.6+4.618 t_{c}-.0523 t_{c}^{2} t^{2} .00023 t_{c}^{3} \\
& +1.25(S-35)-.011(S-35)\left(t_{c}\right)+.0027 \times 10^{-5}(S-35) t_{c}^{4} \\
& -2 \times 10^{-7}(S-35)^{4}\left(1+.577 t_{c}-.0072 t_{c}^{2}\right)
\end{aligned}
$$

The last term of this equation becomes significant as salinity approaches zero, and yields velocities in agreement with experimental values for distilled water $(S=0 \%)$. However, as no determinations were made from 0-19 parts per thousand salinity, the use of this equation in this range of salinities is not recommended. In Table 3 the experimental determinations of velocity are compared with the velocities corresponding to the same physical conditions obtained by the use of the empirical equation. 
No significant difference was observed between the three natural sea water samples obtained from different locations when their measured velocities were compared with the sound velocities obtained by use of the empirical equation. No change in measured sound velocity was detected in any of the natural sea water samples over an approximately twoweek period after receipt.

Table 4 is a comparison of velocity values obtained from Kuwahara's tables and the empirical equation.

Figure 1 and Figures $1 \mathrm{a}-\mathrm{g}$ are graphical representations of this equation in metric units and Figure 2 and Figures 2a-p are the same graphs in British units. Figures 3 and 4 show the temperature dependence of the salinity coefficient of velocity in metric and British units respectively, together with a comparison of Kuwahara's values.

Tables 5, 6, and 7 are the corrections to the velocity of sound in sea water of 35 parts per thousand salinity at $0^{\circ} \mathrm{C}$ temperature and "zero" depth $\left(\mathrm{V}_{0}{ }^{\circ} \mathrm{C}, 35 \mathrm{ppt}, \mathrm{Op}=\right.$ $1448.6 \mathrm{~m} / \mathrm{sec}$ ) for changes in temperature and/or salinity.

Table 5 contains values of $V_{t}$, the temperature correction to the velocity of sound in sea water of $35 \mathrm{ppt}$ salinity referred to a temperature of $0^{\circ} \mathrm{C}$. Table 6 contains values of $\mathrm{V}_{\mathrm{S}}$, the salinity correction to the velocity of sound in sea water at $0^{\circ} \mathrm{C}$ temperature referred to a salinity of $35 \mathrm{ppt}$. Table 7 contains values of $\mathrm{V}_{\mathrm{st}}$, the combined salinitytemperature correction to the velocity of sound in sea water of $35 \mathrm{ppt}$ salinity and $0^{\circ} \mathrm{C}$ temperature for any simultaneous changes of temperature and salinity. These tables are believed to yield values of sound velocity to the same degree of precision as the empirical equation, i.e., better than $\pm 0.2 \mathrm{~m} / \mathrm{sec}$.

\section{THE CONCEPT OF SALINITY}

A word of caution is advisable in the physical interpretation of these tables. The concept of salinity has been established by an International Commission and salinity is defined as "the total amount of solid material in grams contained in one kilogram of sea water when all the carbonate has been converted to oxide, the bromine and iodine replaced by chlorine, and all organic matter completely oxidized" (8). It has been found that "regardless of the absolute concentration, the relative proportions of the different major constituents are virtually constant except in regions of high dilution (low salinity) where minor deviations may occur" (8). * Thus salinity is usually determined by measuring chlorinity, a defined term, now redefined to be made independent of changes in atomic weights thus: "The number giving the chlorinity in grams per kilogram of a sea water sample is identical with the number giving the mass in grams of 'atomic weight silver' just necessary to precipitate the halogens in 0.3285233 kilogram of the sea water sample." Because of changes in atomic weights, the original definition of chlorinity is now called the chlorine-equivalent. The chlorine-equivalent is the quantity determined by the $\mathrm{AgNO}_{3}$ titration, and the ratio of chlorine-equivalent to chlorinity is at present 1.00045 . Neither the chlorine-equivalent nor the chlorinity represent the actual amount of chlorine in a sea water sample; bromine and iodine, as well as chlorine, participate in the $\mathrm{AgNO}_{3}$ titration, whereas fluorine does not. Neither does the salinity, by definition, represent the total quantity of dissolved solids in sea water. The technique of determining the defined salinity, however, yields reproducible results. The following empirical equation has been obtained (8) for the dissolved solids content

$$
\Sigma \%=0.073+1.8110 \mathrm{Cl} \% \text {. }
$$

It can be shown that the total amount of dissolved solids is greater than the defined salinity.

\footnotetext{
Not underlined in the original
} 
The point to be brought forth here is that Knudsen's Hydrographical Tables (in widespread use by oceanographers) have been shown to hold very well over the normal range of the concentration of sea water but are not necessarily valid for highly diluted or concentrated sea water. The diluted samples (from the Baltic Sea) used in preparing Knudsen's tables had been diluted by river water containing relatively large quantities of dissolved solids. Thus, the equation relating salinity to chlorinity shows a salinity of $0.03 \mathrm{ppt}$ for zero chlorinity. The salinity determined by titration of sea water that had been diluted by water containing a lesser quantity of dissolved solids would be smaller that that obtained from Knudsen's tables. Conversely, if the sea water were diluted with water containing a greater quantity of dissolved solids, the salinity obtained from Knudsen's tables would be too low.

The validity of the chlorinity-salinity-density relationships as established by the International Commission depends upon the ratios of the more abundant substances in sea water being virtually constant. However, "chlorinities" determined by titration of sea water diluted by melting sea ice were consistently higher than those computed from density measurements $(10,11)$. In this case, the diluting water was essentially distilled water. The dependence of the $\mathrm{Cl}-\mathrm{S}$-density relations on the dissolved solids content of the diluting water and the restricted application of these relations to highly diluted water occurring naturally or prepared in the laboratory should be kept in mind.

The sea water samples used in this investigation were prepared by evaporation under vacuum or by dilution with distilled water of "mid-ocean" water. Previous work has shown the velocity of sound in sea water to be an approximately linear summation of the velocities of the components (7), and thus the validity of this work also depends on the constancy of the ratios of major constituents of sea water.

\section{VALIDITY OF THESE MEASUREMENTS AT SONAR FREQUENCIES}

A question arises concerning the validity of utilizing at sonar frequencies these velocity measurements obtained at megacycle frequencies. A relaxational phenomenon exists for sea water with a frequency of about $200 \mathrm{kc}$ at $22.5^{\circ} \mathrm{C}$. It is true that a small dispersion of sound velocity accompanies a relaxational absorption, but the generally accepted work of Kneser (13) shows this dispersion to be very small indeed. He gives the expression

$$
\mathrm{V}_{\infty}^{2}-\mathrm{V}_{0}^{2}=\frac{2}{\pi} \alpha_{\mathrm{m}}^{*} \mathrm{~V}_{\mathrm{o}} \mathrm{V}_{\infty}
$$

where $V_{0}$ is the sound velocity at very low frequency, $V_{\infty}$ is the sound velocity at very high frequency, and $\alpha \underset{m}{*}$ is the maximum value of the amplitude coefficient of absorption per wavelength for the relaxational frequency $\mathrm{N}_{\mathrm{m}}$. This can be written approximately as

$$
\frac{\mathrm{V}_{\infty}-\mathrm{V}_{0}}{\mathrm{~V}} \cong \frac{\alpha_{\mathrm{m}}^{*}}{\pi}
$$

Using the approximate value of $50 \times 10^{-6}$ obtained by Wilson (12) for $\alpha$ m and $1.5 \times 10^{5}$ $\mathrm{cm} / \mathrm{sec}$ for $\mathrm{V}, \mathrm{V}_{\infty}-\mathrm{V}_{0} \cong 0.024 \mathrm{~meter} / \mathrm{sec}$, a value which is well within experimental error.

\section{ACKNOWLEDGMENTS}

The author gratefully acknowledges the assistance received in the course of this investigation by many members of the Sound Division of the Naval Research Laboratory. He is especially indebted to R. J. Urick, who suggested the problem, and gave helpful 
advice; to Paul Fougère, ${ }^{*}$ who performed many of the determinations; and to B. J. Schweitzer and C. A. Boudreau for generous help with the calculations.

* Now at Boston College, Chestnut Hill, Mass.

安称

\section{REFERENCES}

1. Stephenson, E. B., "Velocity of Sound in Sea Water," Phys. Rev. 21, Series 2, $181-185$ (1923)

2. Heck, N. H., and Service, J. H., "Velocity of Sound in Sea Water," U.S. Coast and Geodetic Survey, Spec. Publ. No. 108 (1924)

3. Kuwahara, S., "Velocity of Sound in Sea Water and Calculation of the Velocity for Use in Sonic Sounding," Hydrographic Rev. 16, 123-140 (1939)

4. Mathews, D. J., "Tables of Velocity of Sound in Pure Water and Sea Water," 2nd ed. (British Admiralty Publication H. D., 1939), p. 282

5. Wood, A. B., "A Textbook of Sound," 2nd ed. (G. Bell and Sons, London:1941), pp. 261-266

6. Stephenson, E. B., and Woodsmall, F. J., "The Velocity of Sound in Sea Water," NRL Report No. S-1722, 11 April 1941

7. Weissler, A., and Del Grosso, V. A., "The Velocity of Sound in Sea Water," J. Acoust. Soc. Am. 23, 219-223 (1951)

8. Sverdrup, H. U., Johnson, M. W., and Fleming, R. H., "The Oceans," (Prentice Hall, Inc., New York:1942), p. 51 and references contained therein

9. Lyman, J., and Fleming, R. H., J. Marine Research 3, 134-146 (1940)

10. "Scientific Results of Norwegian North Polar Expedition with the Maud," J. Malmgren 1 , No. 5 (1927)

11. Jbid., Sverdrup, H. U., 4, No. 2 (1929)

12. Wilson, O. B., and Leonard, R. W., "Absorption of Ultrasonic Waves in Aqueous Solutions of Magnesium Sulfate," Univ. of California, Dept. of Physics, Tech. Report No. 4, Contract N6 onr-27507, June 1951

13. Bergmann, L., "Der Ultraschall und Seine Anwendung in Wissenschaft und Technik," 5 ed. (S. Hirzel Verlag, Stuttgart, 1949), pp. 344-353 


\section{TABLES AND FIGURES}

Velocity of Sound in Sea Water (irom various tables)

Sea Water Sample Data

Comparison of Experimental Determinations and Values from Empirical Equation

Comparison of Values from Empirical Equation and Kuwahara's Tables

Correction to Standard Velocity for Temperature Change

Correction to Standard Velocity for Salinity Change

Correction to Standard Velocity for Simultaneous Temperature

\section{FIGURES}

Velocity of Sound at Zero Depth Metric Units

Velocity of Sound at Zero Depth Metric Units Expanded Scale

Velocity of Sound at Zero Depth - British Units

Velocity of Sound at Zero Depth - British Units Expanded Scale

Salinity Coefficient of Velocity vs. Temperature Metric Units

Salinity Coefficient of Velocity vs. Temperature 
TABLE 1

Velocity of Sound in Sea Water

(from various tables)

\begin{tabular}{|c|c|c|c|c|c|c|c|}
\hline \multirow{2}{*}{$\begin{array}{c}\text { Depth } \\
(\mathrm{m})\end{array}$} & \multirow{2}{*}{$\begin{array}{c}\text { Temp. } \\
\left({ }^{\circ} \mathrm{C}\right)\end{array}$} & $\begin{array}{c}\text { Sal. } \\
(\% / 00)\end{array}$ & $\begin{array}{c}\text { Heck \& } \\
\text { Service }\end{array}$ & Wood & $\begin{array}{c}\text { Br. Adm. } \\
1927\end{array}$ & $\begin{array}{c}\text { Br. Adm. } \\
1939\end{array}$ & $\begin{array}{c}\text { Kuwahara } \\
1939\end{array}$ \\
\hline 0 & 0 & -35 & 1450 & 1450 & 1445.3 & 1445.4 & 1445.5 \\
0 & 10 & 35 & 1489 & 1488 & 1486.6 & 1486.7 & 1486.8 \\
0 & 20 & 35 & 1514 & 1519 & 1518.6 & 1518.7 & 1518.7 \\
0 & 30 & 35 & -- & 1543 & 1543.0 & 1543.1 & 1543.2 \\
\hline
\end{tabular}

TABLE 2

Sample Data

\begin{tabular}{|c|c|c|c|c|c|c|c|}
\hline \multirow{2}{*}{$\begin{array}{c}\text { Sample } \\
\text { No. }\end{array}$} & \multirow{2}{*}{$\begin{array}{c}\text { Date } \\
\text { Collected }\end{array}$} & \multirow{2}{*}{$\begin{array}{c}\text { Date } \\
\text { Received }\end{array}$} & \multicolumn{2}{|c|}{ Collection Location } & \multirow{2}{*}{$\begin{array}{c}\text { Original } \\
\text { Salinity } \\
(\%)\end{array}$} & \multirow{2}{*}{$\begin{array}{l}\text { Temp. } \\
\text { "in situ" } \\
\left({ }^{\circ} \mathrm{C}\right)\end{array}$} & \multirow{2}{*}{$\begin{array}{c}\text { Exper. } \\
\text { Salinity } \\
(\% / 00)\end{array}$} \\
\hline & & & Lat. & Long. & & & \\
\hline 1 & $7 / 30 / 51$ & $7 / 31 / 51$ & $24^{0} 25^{\prime} \mathrm{N}$ & $81^{0} 26^{\prime} \mathrm{W}$ & 34.27 & 29 & 34.27 \\
\hline 1 & $7 / 30 / 51$ & $7 / 31 / 51$ & $24^{0} 25^{\prime} \mathrm{N}$ & $81^{\circ} 26^{\prime} \mathrm{W}$ & 34.27 & 29 & 40.43 \\
\hline 1 & $7 / 30 / 51$ & $7 / 31 / 51$ & $24^{\circ} 25^{\prime} \mathrm{N}$ & $81^{\circ} 26^{\prime} \mathrm{W}$ & 34.27 & 29 & 29.02 \\
\hline 1 & $7 / 30 / 51$ & $7 / 31 / 51$ & $24^{0} 25^{\prime} \mathrm{N}$ & $81^{\circ} 26^{\prime} W$ & 34.27 & 29 & 19.77 \\
\hline 2 & $8 / 24 / 51$ & $8 / 27 / 51$ & $24^{\circ} 40^{\prime} \mathrm{N}$ & $80^{\circ} 46^{\prime} \mathrm{W}$ & 37.12 & 29 & 37.12 \\
\hline 2 & $8 / 24 / 51$ & $8 / 27 / 51$ & $24^{\circ} 40^{\prime} \mathrm{N}$ & $80^{\circ} 46^{\prime} \mathrm{W}$ & 37.12 & 29 & 31.49 \\
\hline 3 & $8 / 31 / 51$ & $9 / 4 / 51$ & $32^{0} 13^{\prime} \mathrm{N}$ & $69^{\circ} 29^{\prime} \mathrm{W}$ & 37.29 & 28 & 37.29 \\
\hline 3 & $8 / 31 / 51$ & $9 / 4 / 51$ & $32^{\circ} 13^{\prime} \mathrm{N}$ & $69^{\circ} 29^{\prime} \mathrm{W}$ & 37.29 & 28 & 24.20 \\
\hline
\end{tabular}


TABLE 3

Comparison of Experimental Determinations and Values from Empirical Equation

\begin{tabular}{|c|c|c|c|c|}
\hline $\begin{array}{c}\text { Salinity } \\
(\% 00)\end{array}$ & $\begin{array}{c}\text { Temperature } \\
\left({ }^{\circ} \mathrm{C}\right)\end{array}$ & $\begin{array}{c}\text { Vexp. } \\
(\mathrm{m} / \mathrm{sec})\end{array}$ & $\begin{array}{l}\text { Veq. } \\
(\mathrm{m} / \mathrm{sec})\end{array}$ & $\begin{array}{c}V_{\text {exp. }}-V_{\text {eq }} \\
(\mathrm{m} / \mathrm{sec})\end{array}$ \\
\hline \multirow[t]{5}{*}{40.43} & 40.0 & 1569.2 & 1569.1 & +0.1 \\
\hline & 30.2 & 1551.6 & 1551.8 & -0.2 \\
\hline & 20.0 & 1527.5 & 1527.5 & 0.0 \\
\hline & 10.1 & 1496.5 & 1496.3 & +0.2 \\
\hline & 0.0 & 1455.3 & 1455.4 & -0.1 \\
\hline \multirow[t]{8}{*}{37.29} & 39.1 & 1564.9 & 1565.0 & -0.1 \\
\hline & 30.0 & 1548.0 & 1548.2 & -0.2 \\
\hline & 25.0 & 1537.1 & 1537.2 & -0.1 \\
\hline & 20.0 & 1524.3 & 1524.3 & 0.0 \\
\hline & 15.0 & 1509.5 & 1509.4 & +0.1 \\
\hline & 10.0 & 1492.5 & 1492.5 & 0.0 \\
\hline & 5.0 & 1472.9 & 1473.2 & -0.3 \\
\hline & 0.0 & 1451.4 & 1451.5 & -0.1 \\
\hline 37.12 & 29.9 & 1547.7 & 1547.9 & -0.2 \\
\hline \multirow[t]{5}{*}{34.27} & 40.0 & 1563.6 & 1563.6 & +0.2 \\
\hline & 30.0 & 1545.3 & 1545.5 & -0.2 \\
\hline & 20.0 & 1521.3 & 1521.1 & +0.2 \\
\hline & 10.0 & 1489.1 & 1489.0 & +0.1 \\
\hline & 0.0 & 1447.7 & 1447.7 & 0.0 \\
\hline \multirow[t]{5}{*}{31.49} & 40.0 & 1561.3 & 1561.2 & +0.1 \\
\hline & 30.0 & 1542.8 & 1542.6 & +0.2 \\
\hline & 20.0 & 1518.5 & 1518.3 & +0.2 \\
\hline & 10.0 & 1485.8 & 1485.8 & 0.0 \\
\hline & 0.0 & 1444.2 & 1444.2 & 0.0 \\
\hline \multirow[t]{5}{*}{29.02} & 40.0 & 1558.9 & 1559.0 & -0.1 \\
\hline & 30.0 & 1540.5 & 1540.6 & -0.1 \\
\hline & 20.0 & 1515.9 & 1515.7 & +0.2 \\
\hline & 10.0 & 1483.1 & 1482.9 & +0.2 \\
\hline & 0.0 & 1441.1 & 1441.1 & 0.0 \\
\hline \multirow[t]{5}{*}{24.20} & 40.0 & J 554.8 & 1554.9 & -0.1 \\
\hline & 30.0 & 1536.1 & 1536.1 & 0.0 \\
\hline & 20.0 & 1510.9 & 1510.8 & +0.1 \\
\hline & 10.0 & 1477.5 & 1477.5 & 0.0 \\
\hline & 0.0 & 1434.9 & 1435.1 & -0.2 \\
\hline \multirow[t]{6}{*}{19.77} & 40.0 & 1551.1 & 1551.0 & +0.1 \\
\hline & 30.0 & 1532.2 & 1531.9 & +0.3 \\
\hline & 20.0 & 1506.4 & 1506.2 & +0.2 \\
\hline & 10.0 & 1472.6 & 1472.5 & +0.1 \\
\hline & 5.0 & 1452.1 & 1452.2 & -0.1 \\
\hline & 0.0 & .1429 .7 & 1429.6 & +0.1 \\
\hline \multirow[t]{8}{*}{0} & 40.0 & 1529.5 & 1529.7 & -0.2 \\
\hline & 35.0 & 1520.9 & 1520.7 & +0.2 \\
\hline & 30.0 & 1509.9 & 1509.6 & +0.3 \\
\hline & 25.0 & 1496.8 & 1497.0 & -0.2 \\
\hline & 20.0 & 1483.1 & 1482.7 & +0.4 \\
\hline & 15.0 & 1466.5 & 1466.5 & 0.0 \\
\hline & 10.0 & 1448.0 & 1448.0 & 0.0 \\
\hline & 5.0 & 1427.0 & 1427.4 & -0.4 \\
\hline 0 & 0.0 & -- & 1404.5 & -- \\
\hline
\end{tabular}


TABLE 4

Comparison of Velocity Values frcm Empirical Equations and Kuwahara's Tables

\begin{tabular}{|c|c|c|c|c|c|c|}
\hline \multirow{3}{*}{$\begin{array}{c}\text { Temp } \\
\left({ }^{\circ} \mathrm{C}\right)\end{array}$} & \multicolumn{6}{|c|}{ Meters per Second } \\
\hline & \multicolumn{2}{|c|}{$\mathrm{S}=31 \mathrm{ppt}$} & \multicolumn{2}{|c|}{$\mathrm{s}=35 \mathrm{ppt}$} & \multicolumn{2}{|c|}{$S=39 \mathrm{ppt}$} \\
\hline & Kuwahara & NRL & Kuwahara & NRL & Kuwahera & NRL \\
\hline 0 & 1440.3 & 1443.7 & 1445.5 & 1448.6 & 1450.7 & 1453.7 \\
\hline 1 & 44.8 & 48.1 & 50.0 & 53.0 & 55.2 & 58.1 \\
\hline 2 & 49.4 & 52.6 & 54.5 & 57.5 & 59.6 & 62.4 \\
\hline 3 & 53.8 & 57.0 & 58.9 & 61.9 & 64.0 & 66.7 \\
\hline 4 & 58.1 & 61.2 & 63.1 & 66.0 & 68.1 & 71.0 \\
\hline 5 & 1462.3 & 1465.5 & 1467.3 & 1470.4 & 1472.3 & 1475.2 \\
\hline 6 & 66.5 & 69.6 & 71.4 & 74.5 & 76.3 & 79.2 \\
\hline 7 & 70.5 & 73.6 & 75.4 & 78.4 & 80.3 & 83.1 \\
\hline 8 & 74.5 & 77.4 & 79.3 & 82.2 & 84.2 & 87.0 \\
\hline 9 & 78.3 & 81.2 & 83.1 & 86.0 & 87.9 & 90.7 \\
\hline 10 & 1482.0 & 85.1 & 1486.8 & 1488.8 & 1491.6 & 1494.4 \\
\hline 11 & 85.7 & 88.7 & 90.4 & 93.4 & 95.1 & 97.9 \\
\hline 12 & 89.2 & 92.2 & 93.9 & 97.0 & 98.6 & 1501.3 \\
\hline 13 & 92.7 & 95.7 & 97.3 & 1500.3 & 1502.0 & 04.7 \\
\hline 14 & 96.0 & 99.0 & 1500.6 & 03.6 & 05.2 & 08.0 \\
\hline 15 & 1499.3 & 1502.4 & 1503.9 & 1506.9 & 1538.5 & 1511.2 \\
\hline 16 & 1502.5 & 05.6 & 07.0 & 10.0 & 11.5 & 14.2 \\
\hline 17 & 05.6 & 08.8 & 10.1 & 13.0 & 14.6 & 17.2 \\
\hline 18 & 08.6 & 11.8 & 13.0 & 16.0 & 17.5 & 20.2 \\
\hline 19 & 11.5 & 14.8 & 15.9 & 19.0 & 20.3 & 23.1 \\
\hline 20 & 1514.3 & 1517.8 & 1518.7 & 1521.9 & 1523.1 & 1526.0 \\
\hline 21 & 17.2 & 20.6 & 21.5 & 24.7 & 25.9 & 28.7 \\
\hline 22 & 19.8 & 23.2 & 24.1 & 27.3 & 28.4 & 31.3 \\
\hline 23 & 22.4 & 25.9 & 26.7 & 29.9 & 31.0 & 33.9 \\
\hline 24 & 25.0 & 28.4 & 29.2 & 32.4 & 33.5 & 36.4 \\
\hline 25 & 1527.5 & 1531.0 & 1531.7 & 1535.0 & 1535.9 & 1538.8 \\
\hline 26 & 29.9 & 33.4 & 34.1 & 37.3 & 38.3 & 41.2 \\
\hline 27 & 32.3 & 35.8 & 36.4 & 39.6 & 40.6 & 43.5 \\
\hline 28 & 34.6 & 38.0 & 38.7 & 41.9 & 42.9 & 45.8 \\
\hline 29 & 36.9 & 40.3 & 41.0 & 44.1 & 45.1 & 48.0 \\
\hline 30 & 1539.1 & 1542.5 & 1543.2 & 1546.3 & 1547.3 & 1550.2 \\
\hline
\end{tabular}


TABLE 5

Correction $V_{t}$ to $V\left(0^{\circ} \mathrm{C}, 35 \mathrm{ppt}, \mathrm{OP}_{\mathrm{P}}\right)=1448.6 \mathrm{~m} / \mathrm{sec}$ for Changes in Temperature

\begin{tabular}{|c|c|c|c|c|c|c|c|c|c|c|}
\hline $\begin{array}{c}\mathrm{T} \\
\left({ }^{\circ} \mathrm{C}\right)\end{array}$ & 0 & .1 & .2 & .3 & .4 & .5 & .6 & .7 & .8 & .9 \\
\hline 0 & 0.0 & 0.4 & 0.9 & 1.3 & 1.8 & 2.2 & 2.6 & 3.1 & 3.5 & 4.0 \\
\hline 1 & 4.4 & 4.8 & 5.3 & 5.7 & 6.2 & 6.6 & 7.0 & 7.5 & 7.9 & 8.4 \\
\hline 2 & . 8.8 & 9.2 & 9.7 & 10.1 & 10.6 & 11.0 & 11.4 & 11.9 & 12.3 & 12.8 \\
\hline 3 & 13.2 & 13.6 & 14.1 & 14.5 & 14.9 & 15.4 & 15.8 & 16.2 & 16.6 & 17.1 \\
\hline 4 & 17.5 & 17.9 & 18.4 & 18.8 & 19.2 & 19.7 & 20.1 & 20.5 & 20.9 & 21.4 \\
\hline 5 & 21.8 & 22.2 & 22.6 & 23.0 & 23.4 & 23.8 & 24.3 & 24.7 & 25.1 & 25.5 \\
\hline 6 & 25.9 & 26.3 & 26.7 & 27.1 & 27.5 & 27.9 & 28.2 & 28.6 & 29.0 & 29.4 \\
\hline 7 & 29.8 & 30.2 & 30.6 & 30.9 & 31.3 & 31.7 & 32.1 & 32.5 & 32.8 & 33.2 \\
\hline 8 & 33.6 & 34.0 & 34.4 & 34.7 & 35.1 & 35.5 & 35.9 & 36.3 & 36.6 & 37.0 \\
\hline 9 & 37.4 & 37.8 & 38.2 & 38.5 & 38.9 & 39.3 & 39.7 & 40.1 & 40.4 & 40.8 \\
\hline 10 & 41.2 & 41.6 & 41.9 & 42.3 & 42.6 & 43.0 & 43.4 & 43.7 & 44.1 & 44.4 \\
\hline 11 & 44.8 & 45.2 & 45.5 & 45.9 & 46.2 & 46.6 & 47.0 & 47.3 & 47.7 & 48.0 \\
\hline 12 & 48.4 & 48.7 & 49.1 & 49.4 & 49.7 & 50.0 & 50.4 & 50.7 & 51.0 & 51.4 \\
\hline 13 & 51.7 & 52.0 & 52.4 & 52.7 & 53.0 & 53.3 & 53.7 & 54.0 & 54.3 & 54.7 \\
\hline 14 & 55.0 & 55.3 & 55.7 & 56.0 & 56.3 & 56.6 & 57.0 & 57.3 & 57.6 & 58.0 \\
\hline 15 & 58.3 & 58.6 & 58.9 & 59.2 & 59.5 & 59.9 & 60.2 & 60.5 & 60.8 & 61.1 \\
\hline 16 & 61.4 & 61.7 & 62.0 & 62.3 & 62.6 & 62.9 & 63.2 & 63.5 & 63.8 & 64.1 \\
\hline 17 & 64.4 & 64.7 & 65.0 & 65.3 & 65.6 & 65.9 & 66.2 & 66.5 & 66.8 & 67.1 \\
\hline 18 & 67.4 & 67.7 & 68.0 & 68.3 & 68.6 & 68.9 & 69.2 & 69.5 & 69.8 & 70.1 \\
\hline 19 & 70.4 & 70.7 & 71.0 & 71.3 & 71.6 & 71.8 & 72.1 & 72.4 & 72.7 & 73.0 \\
\hline 20 & 73.3 & 73.6 & 73.9 & 74.1 & 74.4 & 74.7 & 75.0 & 75.3 & 75.5 & 75.8 \\
\hline 21 & 76.1 & 76.4 & 76.6 & 76.9 & 77.1 & 77.4 & 77.7 & 77.9 & 78.2 & 78.4 \\
\hline 22 & 78.7 & 79.0 & 79.2 & 79.5 & 79.7 & 80.0 & 80.3 & 80.5 & 80.8 & 81.0 \\
\hline 23 & 81.3 & 81.5 & 81.8 & 82.1 & 82.3 & 82.5 & 82.8 & 83.1 & 83.3 & 83.5 \\
\hline 24 & 83.8 & 84.0 & 84.3 & 84.6 & 84.8 & 85.0 & 85.3 & 85.6 & 85.8 & 86.0 \\
\hline 25 & 86.3 & 86.5 & 86.8 & 87.0 & 87.3 & 87.5 & 87.7 & 88.0 & 88.2 & 88.5 \\
\hline 26 & 88.7 & 88.9 & 89.2 & 89.4 & 89.6 & 89.9 & 90.1 & 90.3 & 90.5 & 90.8 \\
\hline 27 & 91.0 & 91.2 & 91.5 & 91.7 & 91.9 & 92.2 & 92.4 & 92.6 & 92.8 & 93.1 \\
\hline 28 & 93.3 & 93.5 & 93.7 & 94.0 & 94.2 & 94.4 & 94.8 & 94.8 & 95.1 & 95.3 \\
\hline 29 & 95.5 & 95.7 & 95.9 & 96.2 & 96.4 & 96.6 & 96.8 & 97.0 & 97.3 & 97.5 \\
\hline 30 & 97.7 & 97.9 & 98.1 & 98.3 & 98.5 & 98.7 & 99.0 & 99.2 & 99.4 & 99.6 \\
\hline 31 & 99.8 & 100.0 & 100.2 & 100.4 & 100.6 & 100.8 & 101.1 & 101.3 & 101.5 & 101.7 \\
\hline 32 & 101.9 & 102.1 & 102.3 & 102.5 & 102.7 & 102.9 & 103.2 & 103.4 & 103.6 & 103.8 \\
\hline 33 & 104.0 & 104.2 & 104.4 & 104.6 & 104.8 & 105.0 & 105.2 & 105.4 & 105.6 & 105.8 \\
\hline 34 & 106.0 & 106.2 & 106.4 & 106.6 & 106.8 & 107.0 & 107.1 & 107.3 & 107.5 & 107.7 \\
\hline 35 & 107.9 & 108.1 & 108.3 & 108.4 & 108.6 & 108.8 & 109.0 & 109.2 & 109.3 & 109.5 \\
\hline 36 & 109.7 & 109.9 & 110.1 & 110.2 & 110.4 & 110.6 & 110.8 & 111.0 & 111.1 & 111.3 \\
\hline 37 & 111.5 & 111.7 & 111.8 & 111.9 & 112.1 & 112.3 & 112.4 & 112.5 & 112.7 & 112.9 \\
\hline 38 & 113.0 & 113.2 & 113.3 & 113.4 & 113.6 & 113.8 & 113.9 & 114.0 & 114.2 & 114.4 \\
\hline 39 & 114.5 & 114.6 & 114.7 & 114.9 & 115.0 & 115.1 & 115.2 & 115.3 & 115.5 & 115.6 \\
\hline 40 & 115.7 & & & & & & & & & \\
\hline
\end{tabular}




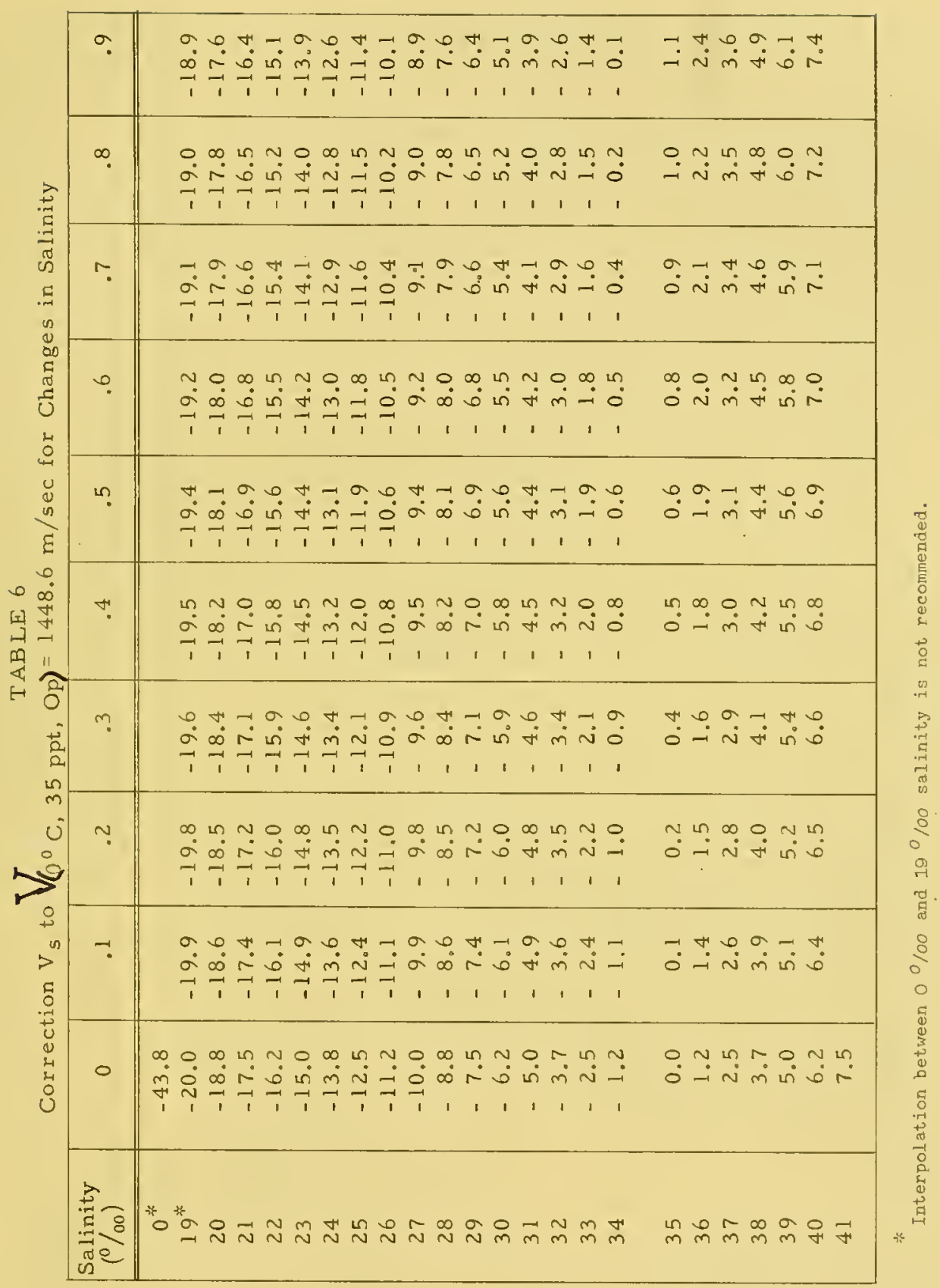




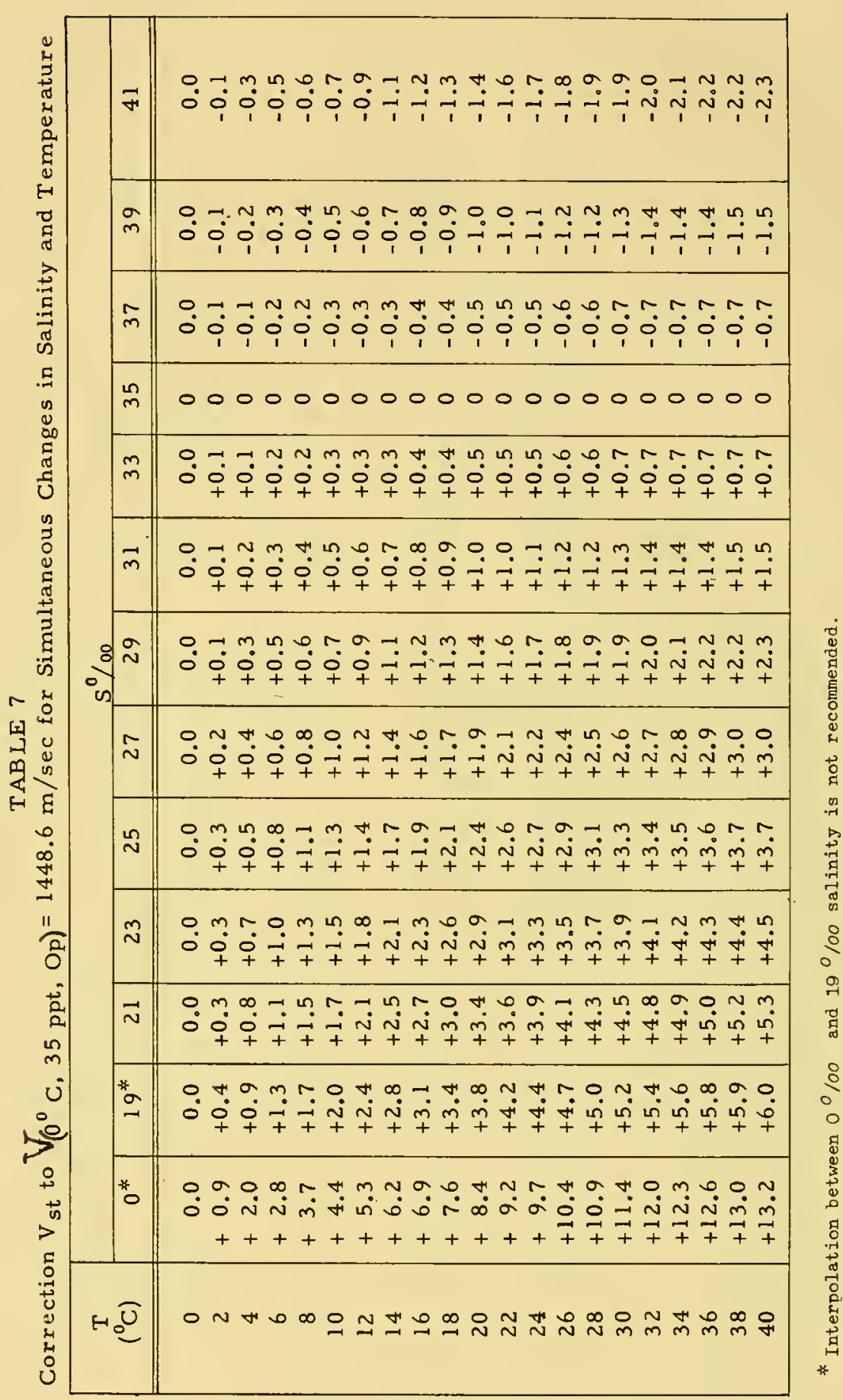




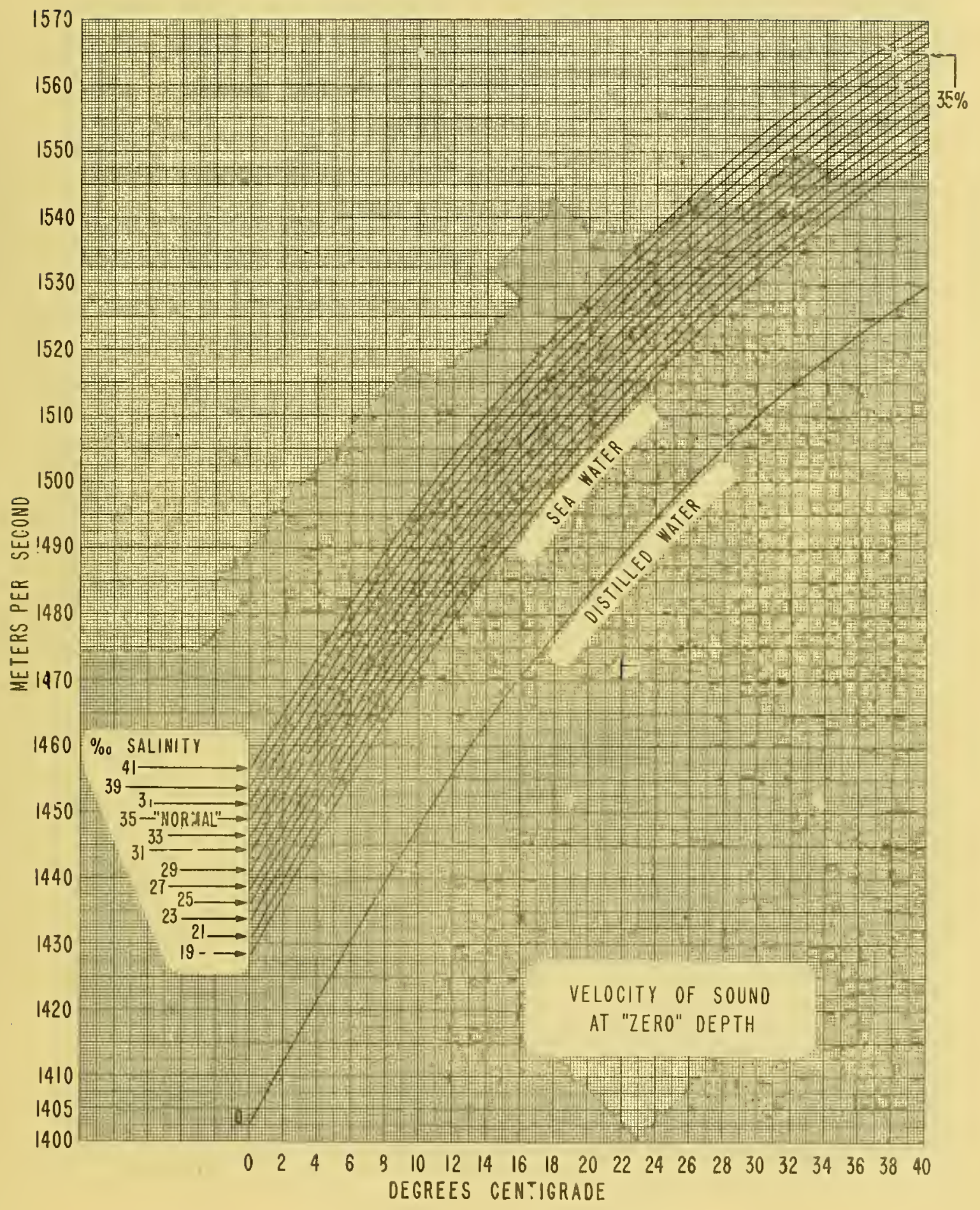

Figure 1 - Velocity of Sound at Zero Depth Metric Units 


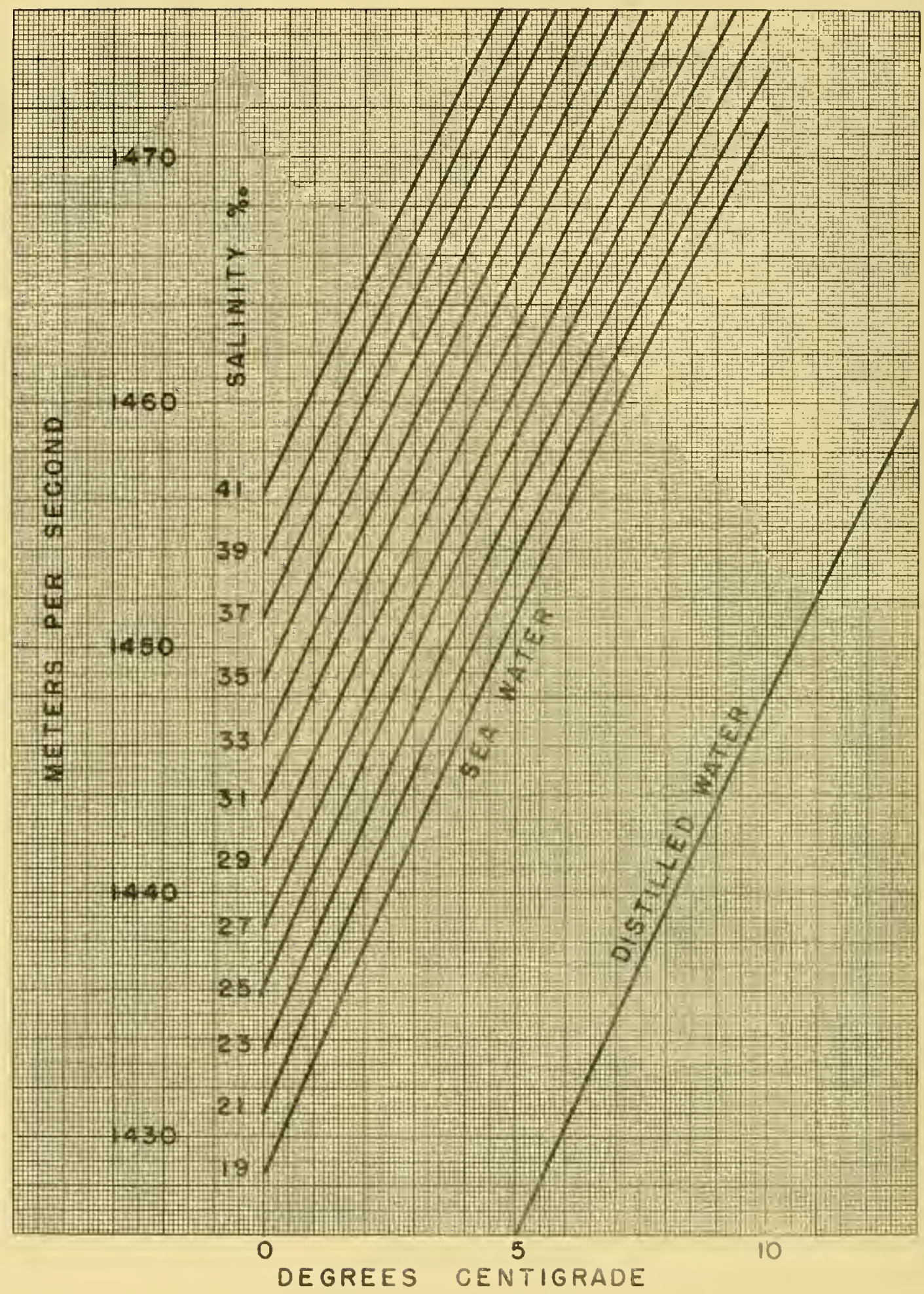

Figure 1-a

Figure I a-g - Velocity of Sound at Zero Depth Metric Units - Expanded Scale 


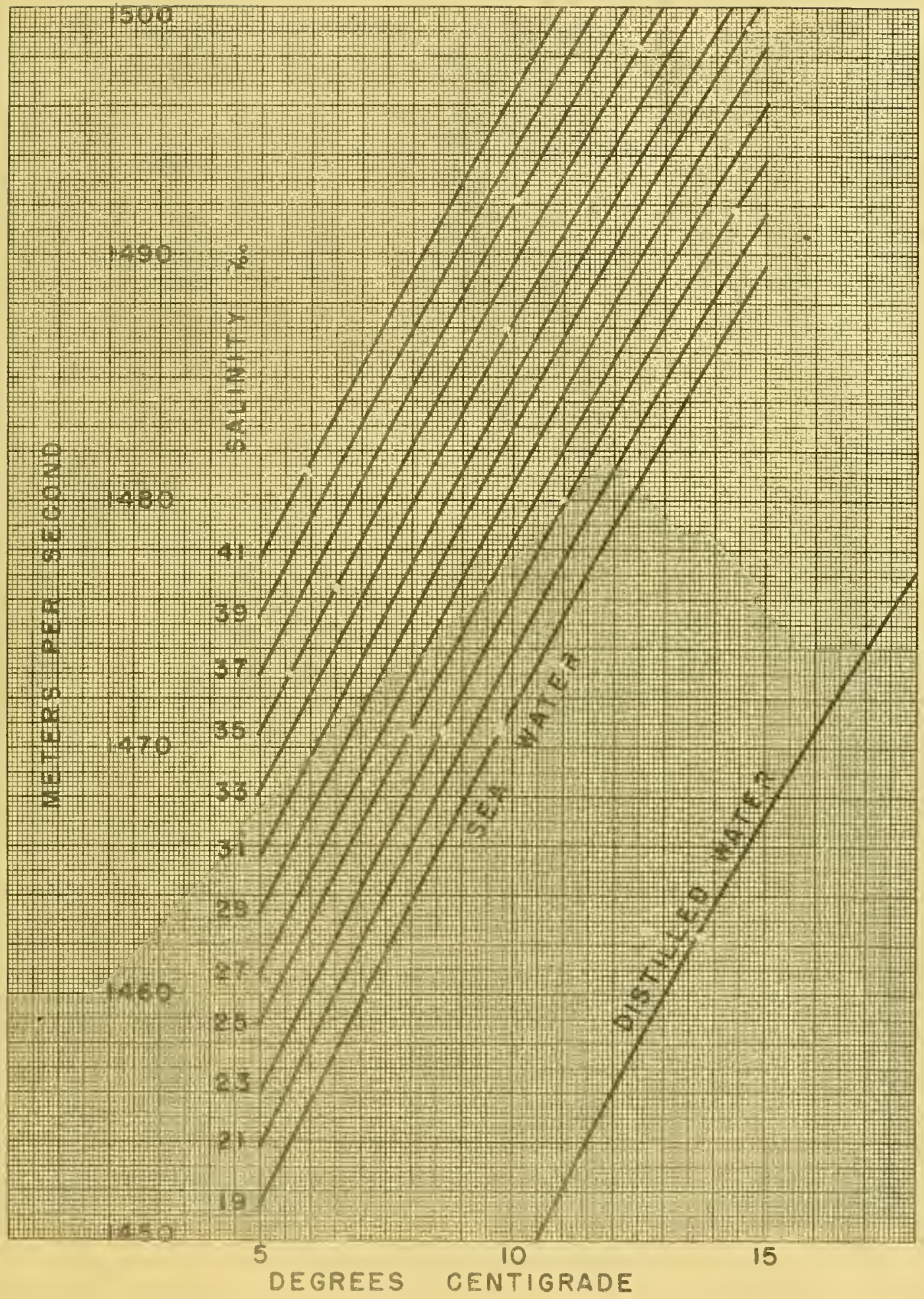

Figure $1-b$ 


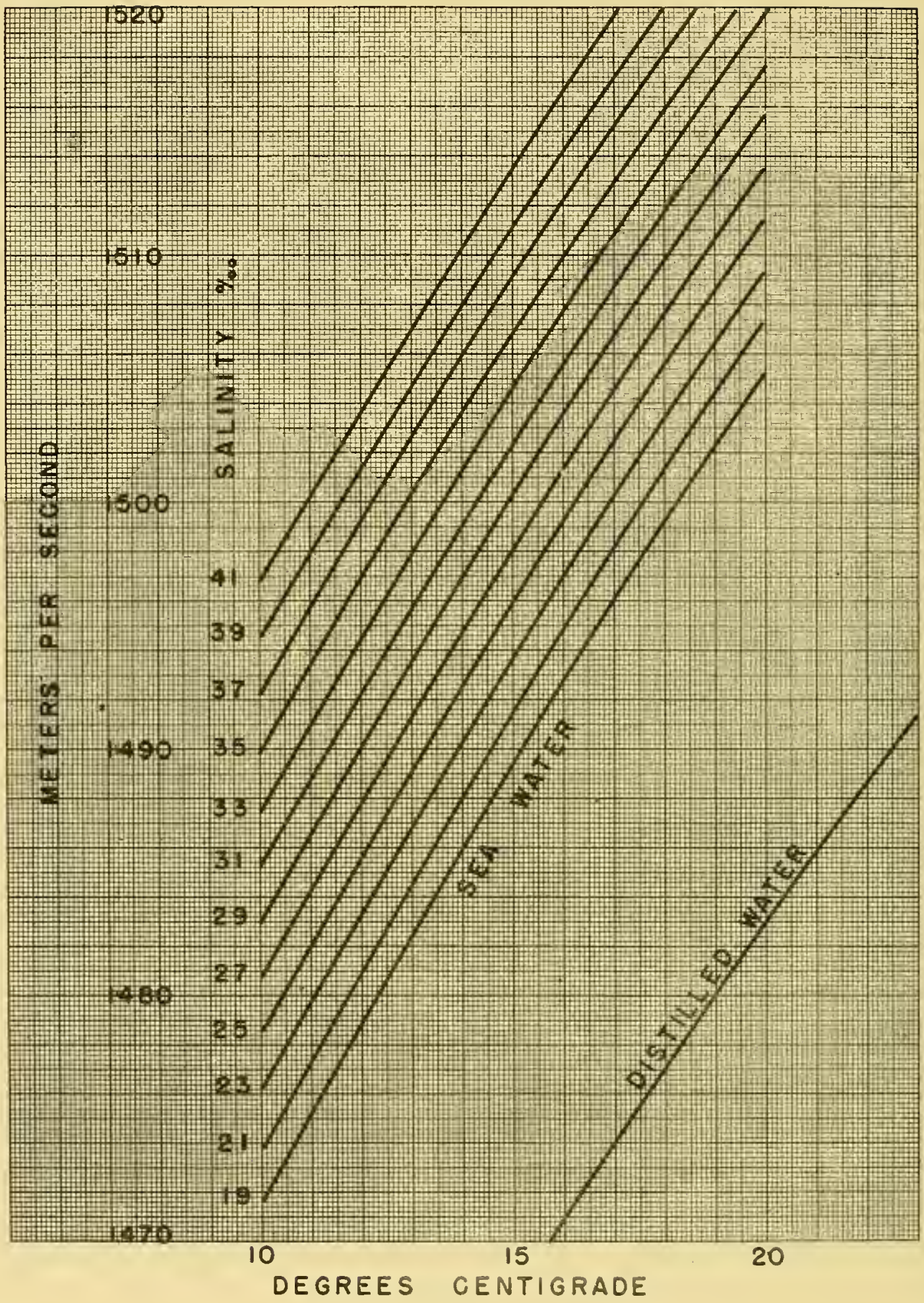

Figure 1-c 


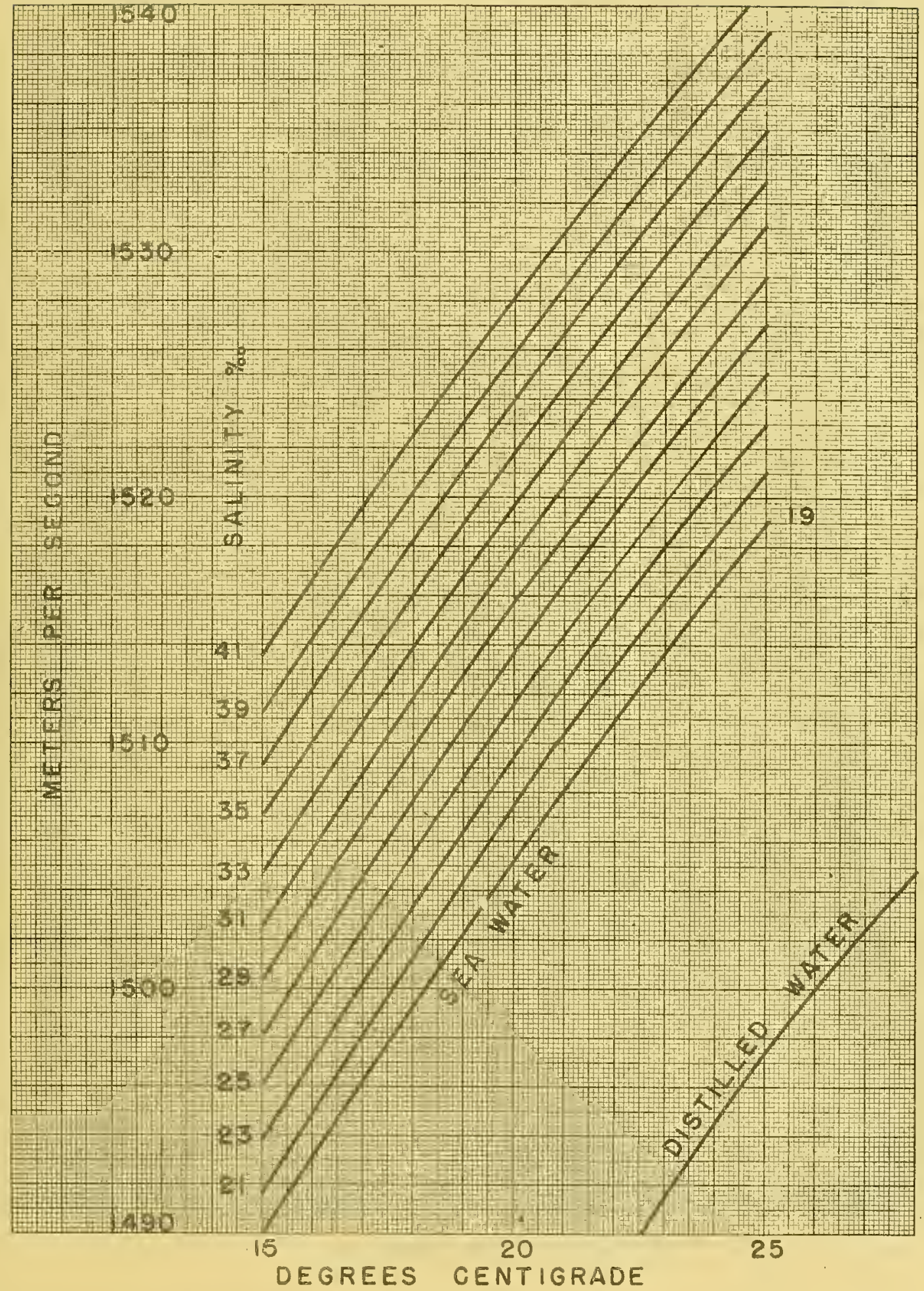

Figure l-d 


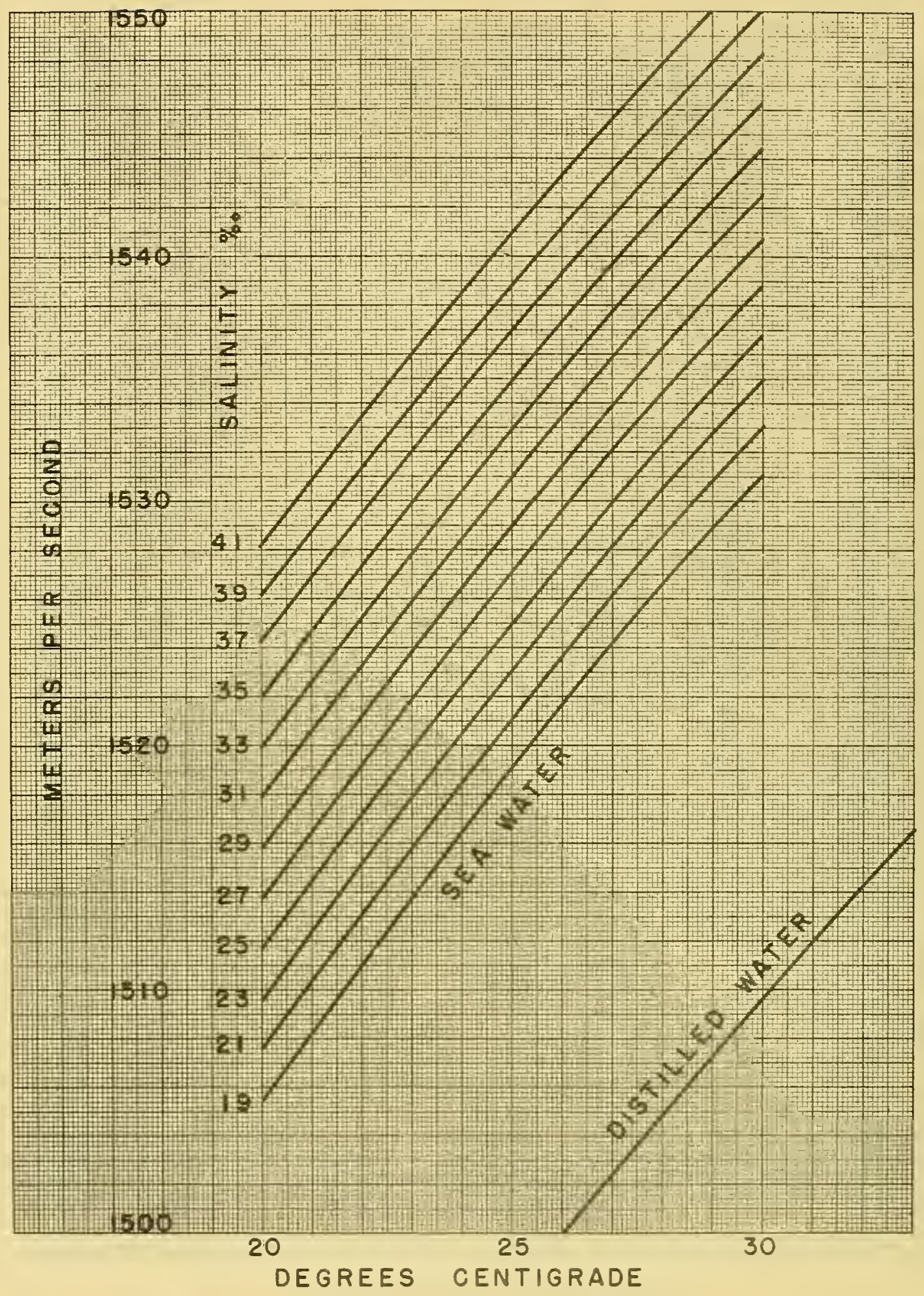

Figure 1-e 


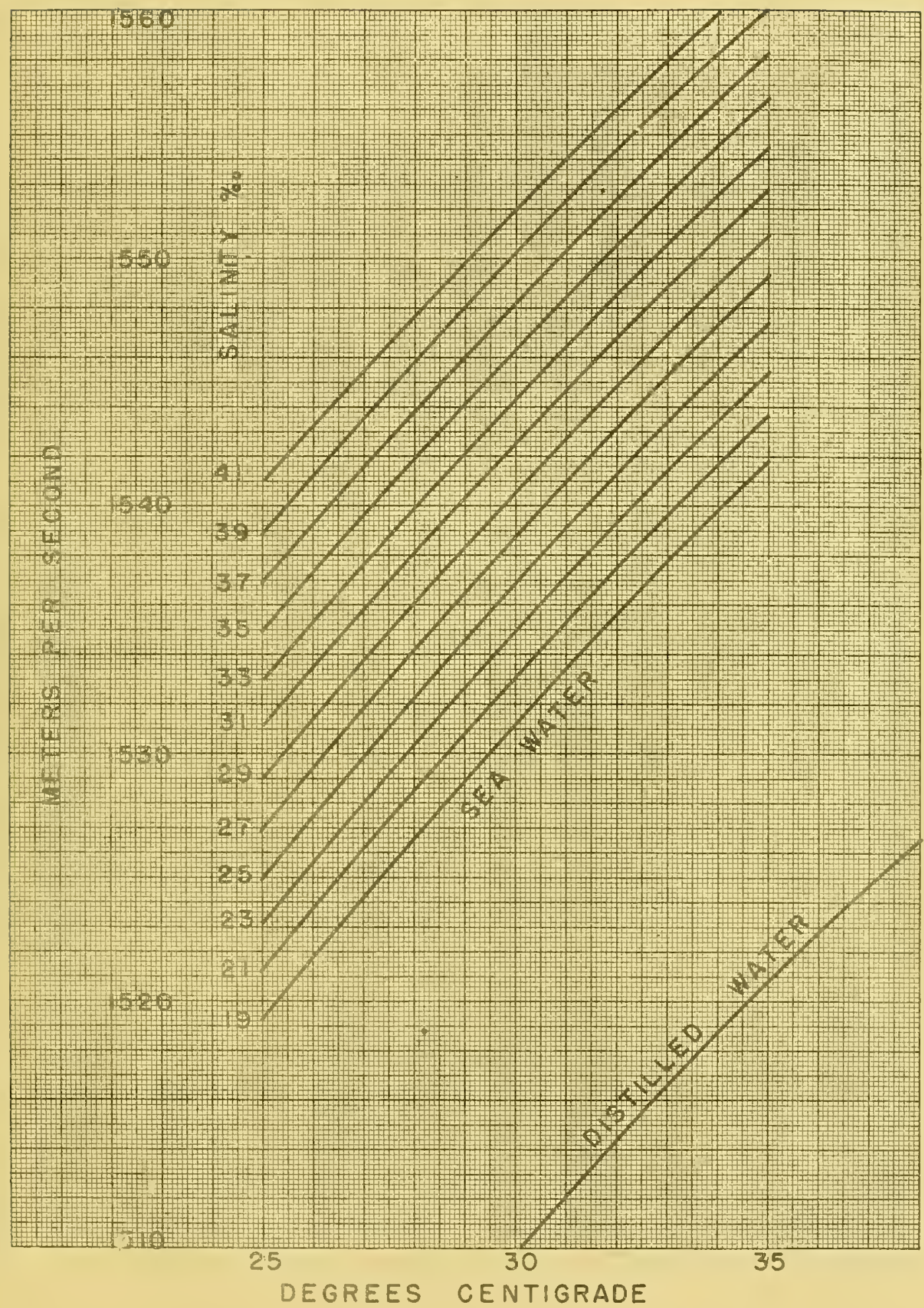

Figure I-f 


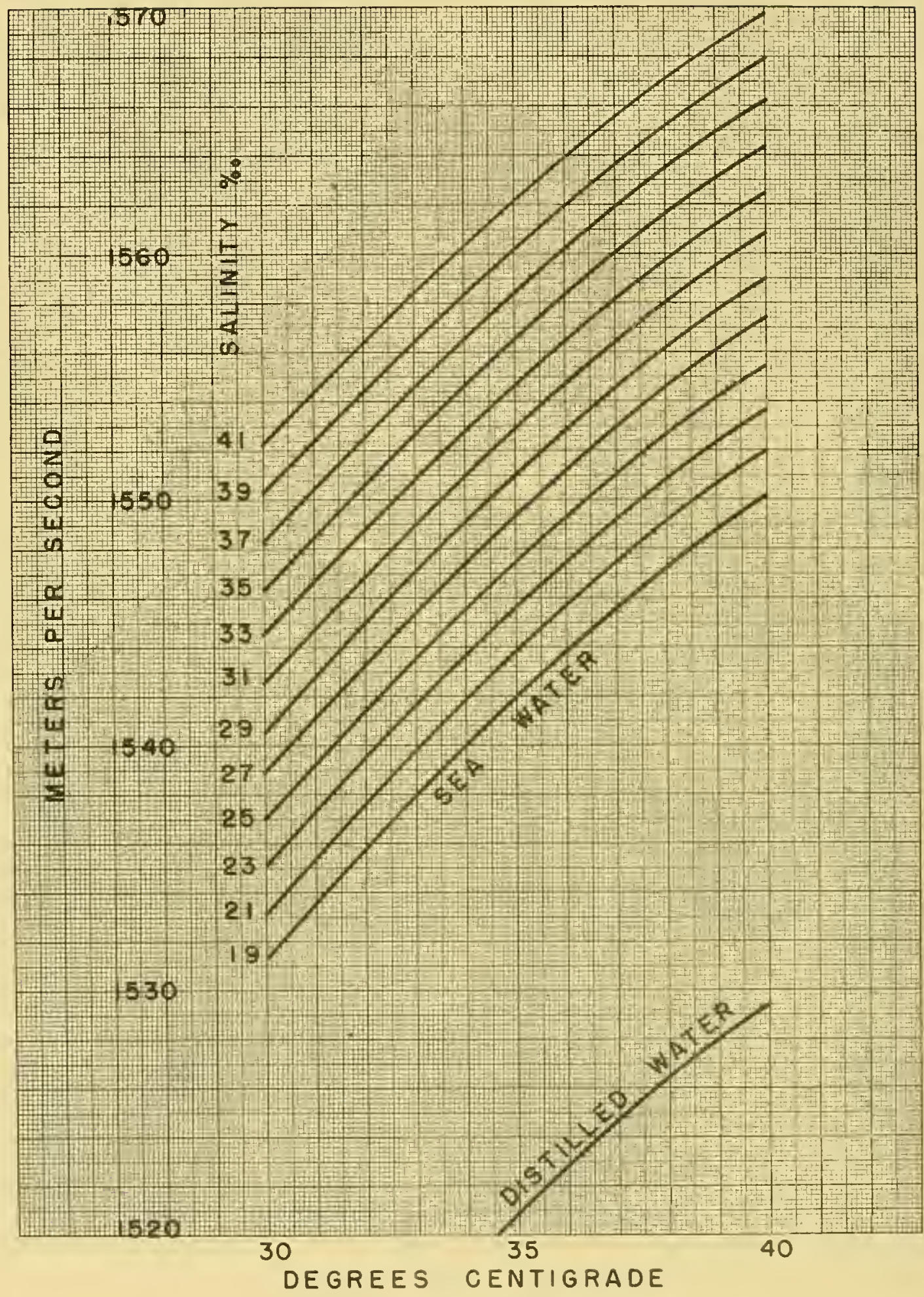

Figure 1-g 


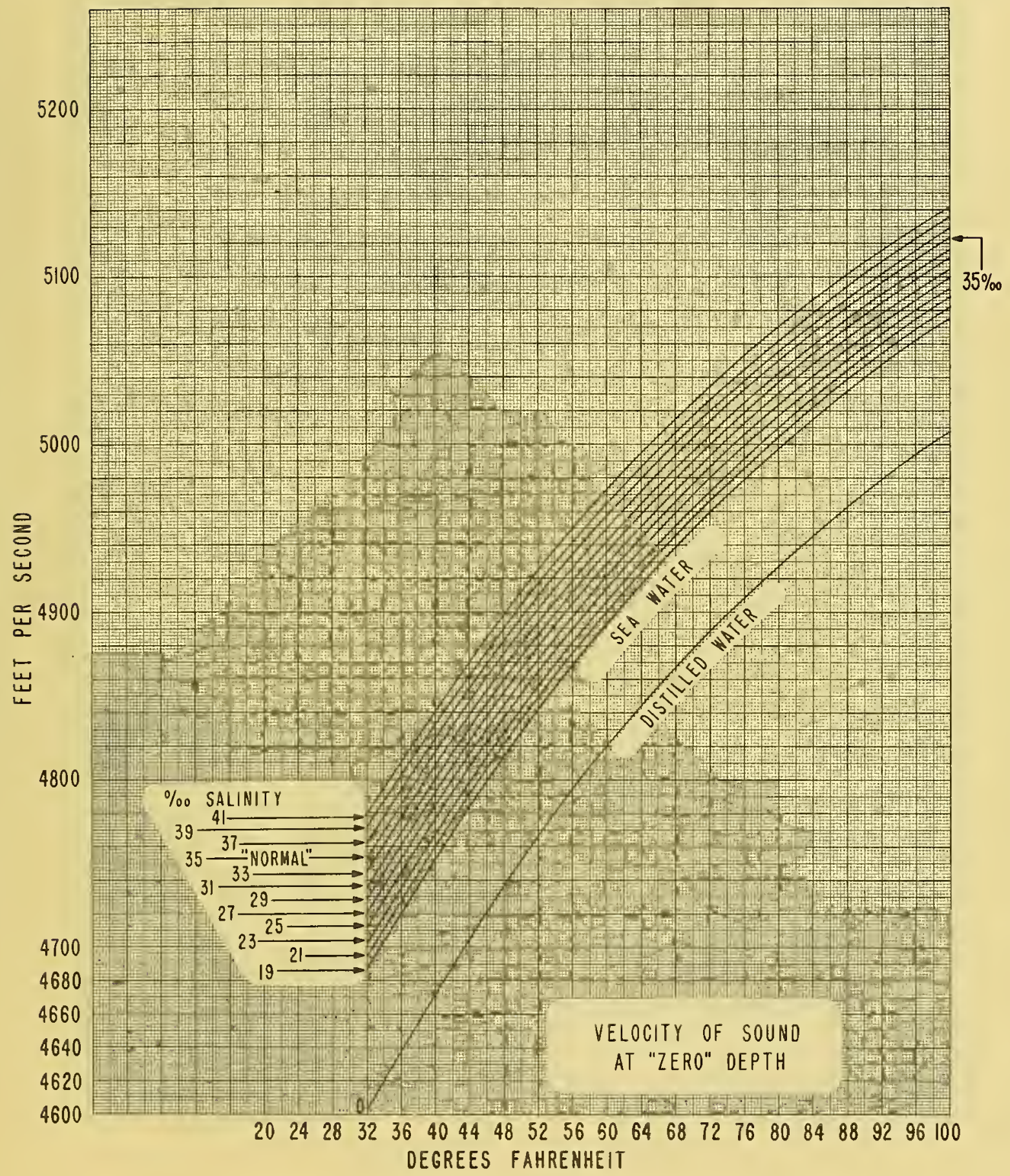

Figure 2 - Velocity of Sound at Zero Depth - British Units 


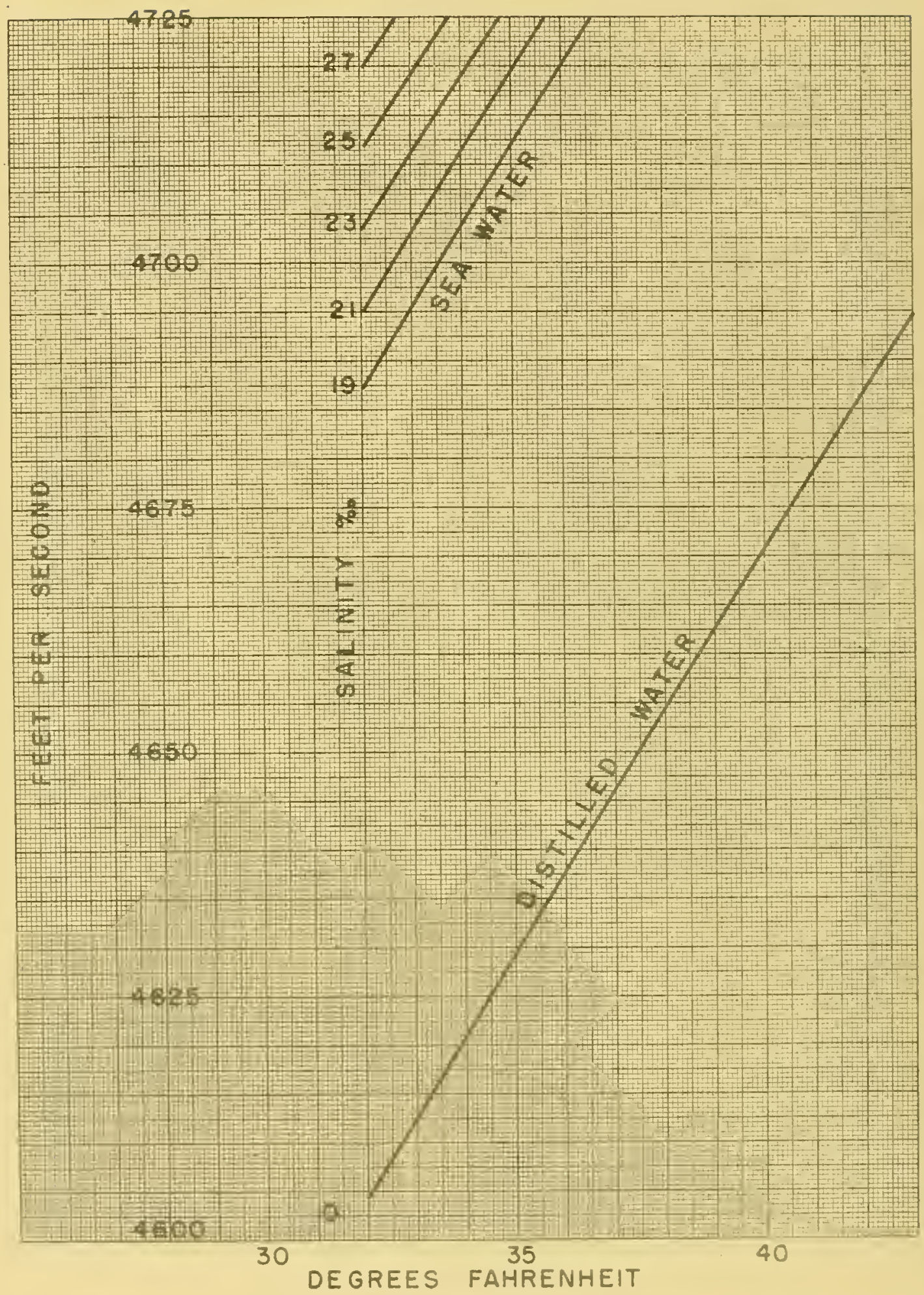

Figure 2-a

Figure $2 \mathrm{a}-\mathrm{p}$ - Velocity of Sound at Zero Depth - British Units Expanded Scale 


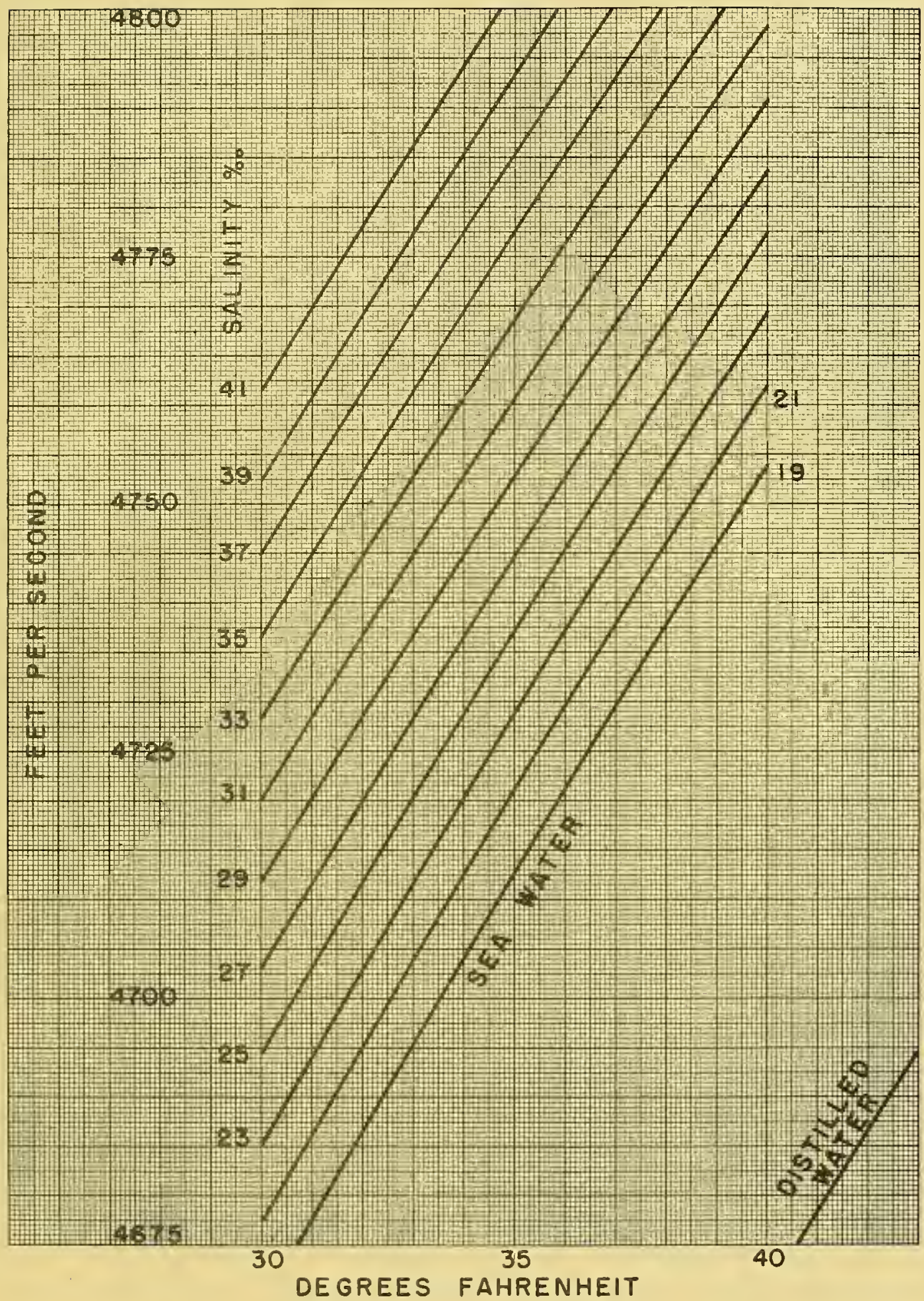

Figure 2-b 


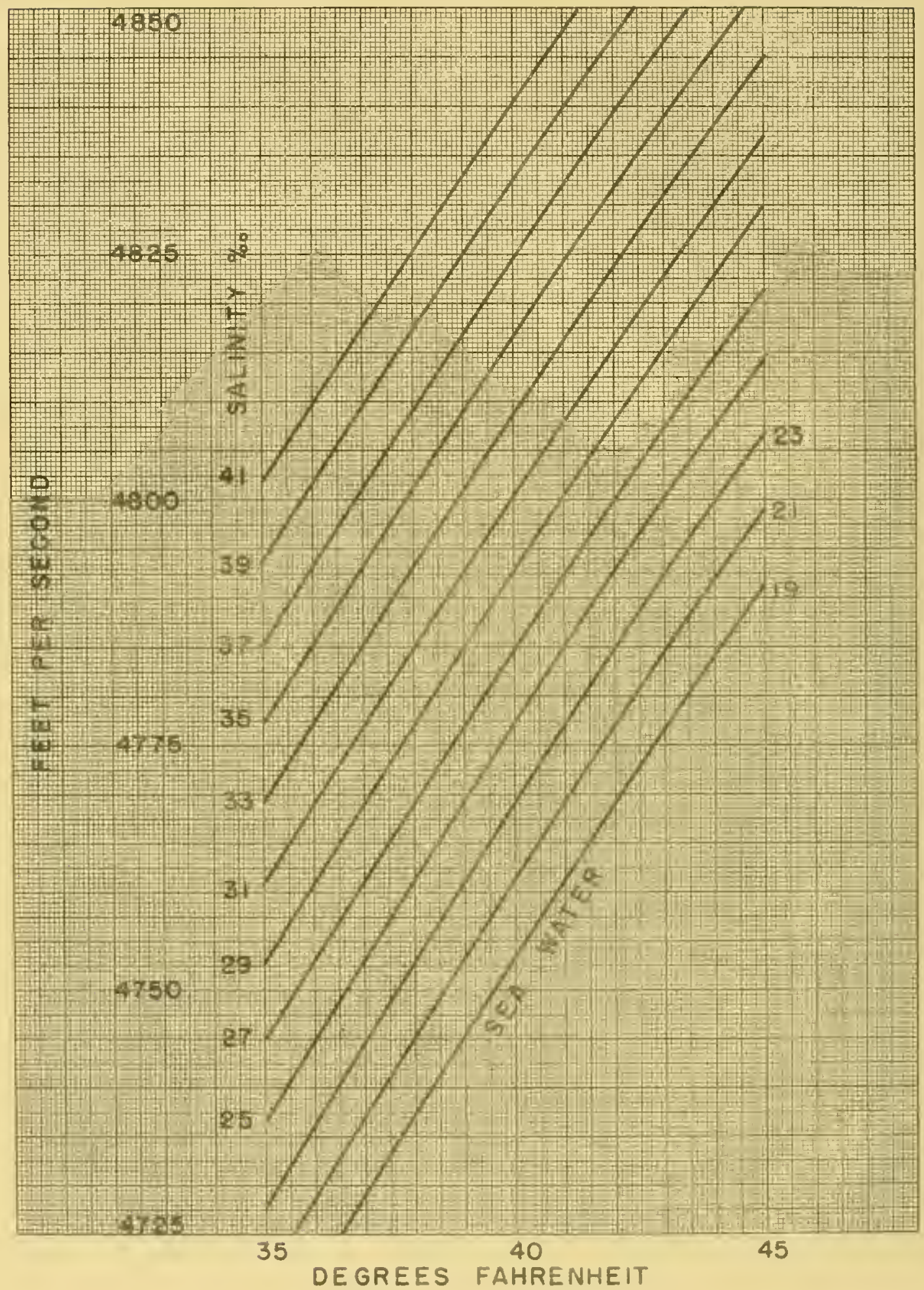

Figure 2-0 


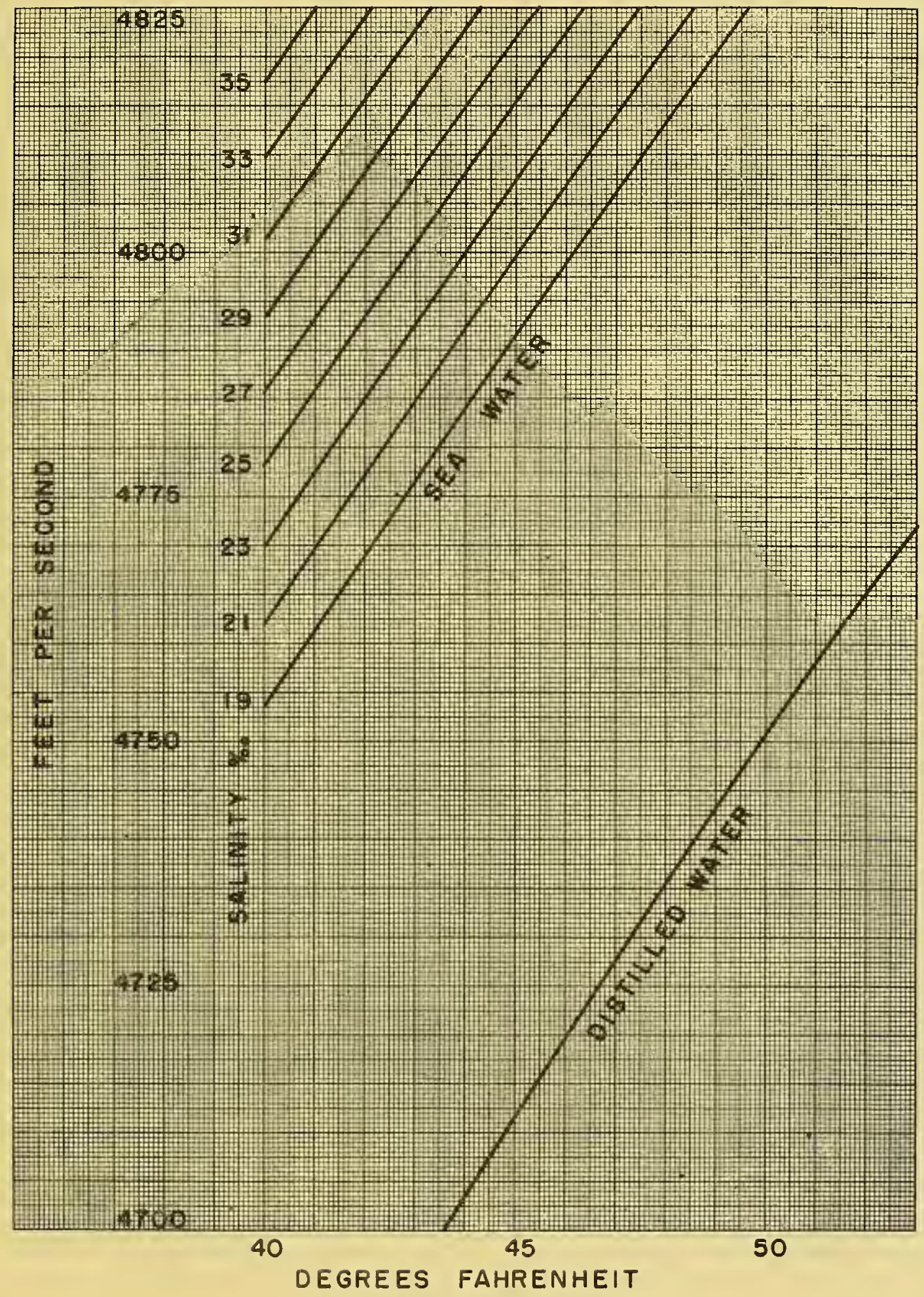

Figure 2-d 


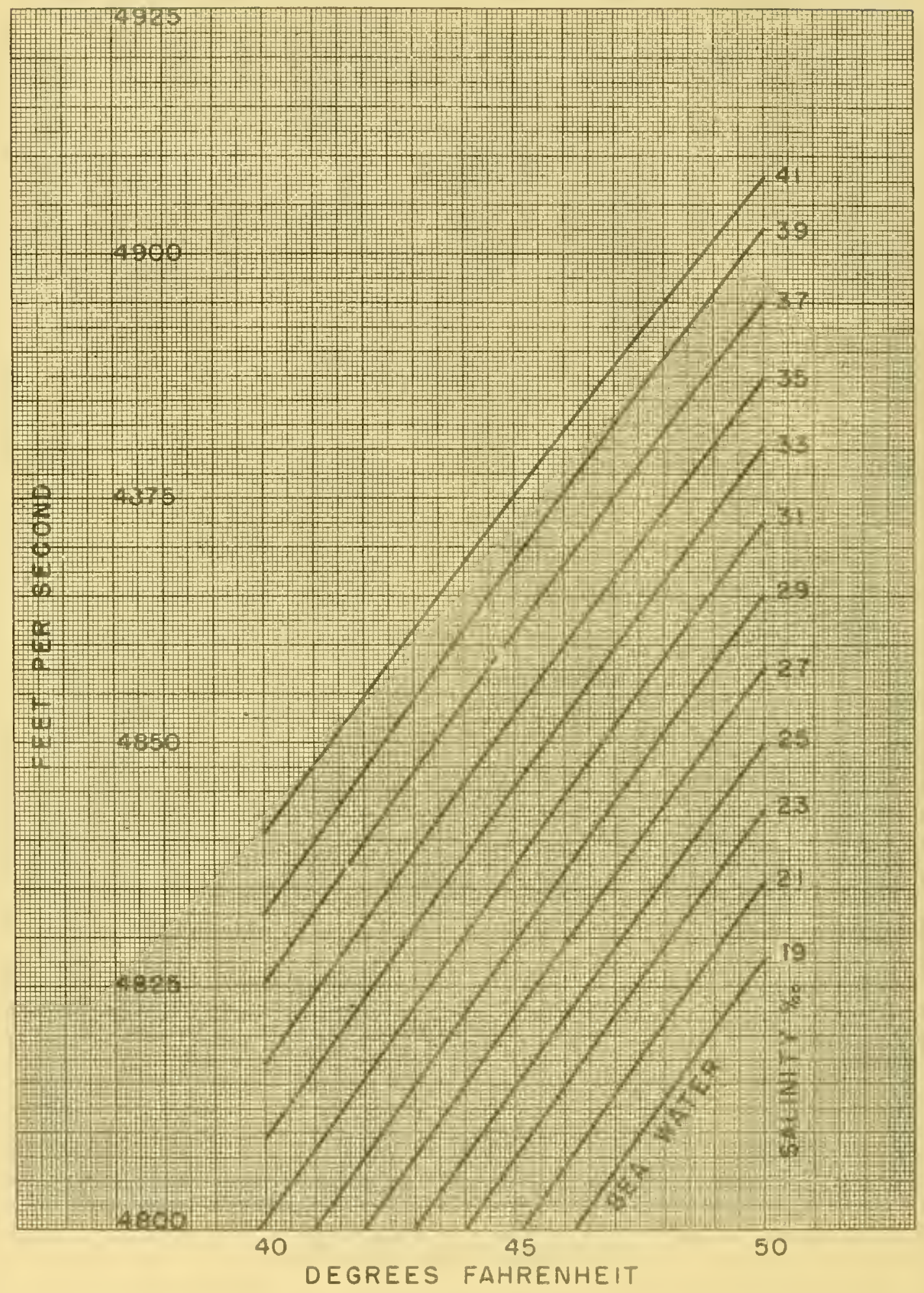

Figure 2-e 


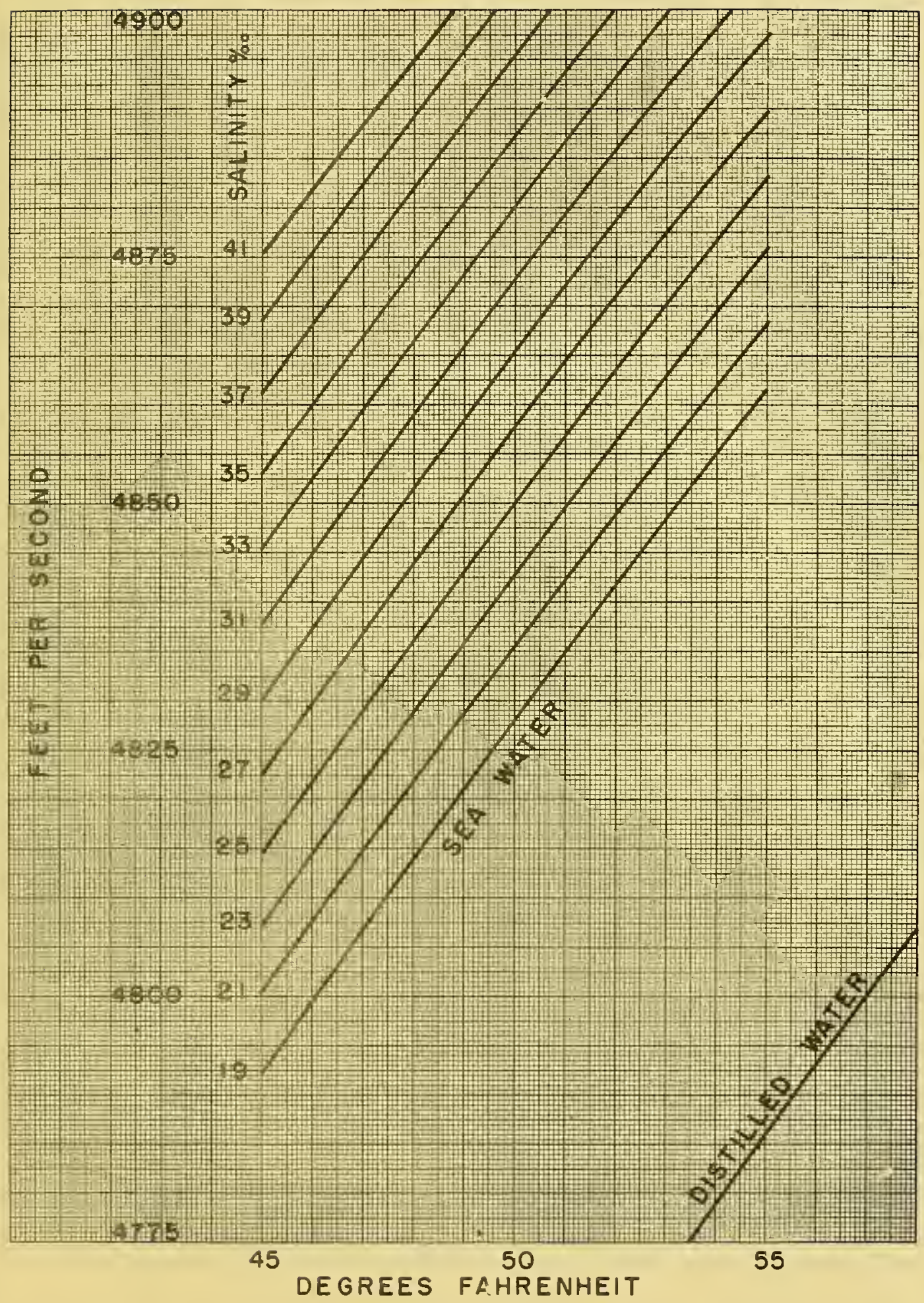

Figure 2-f 


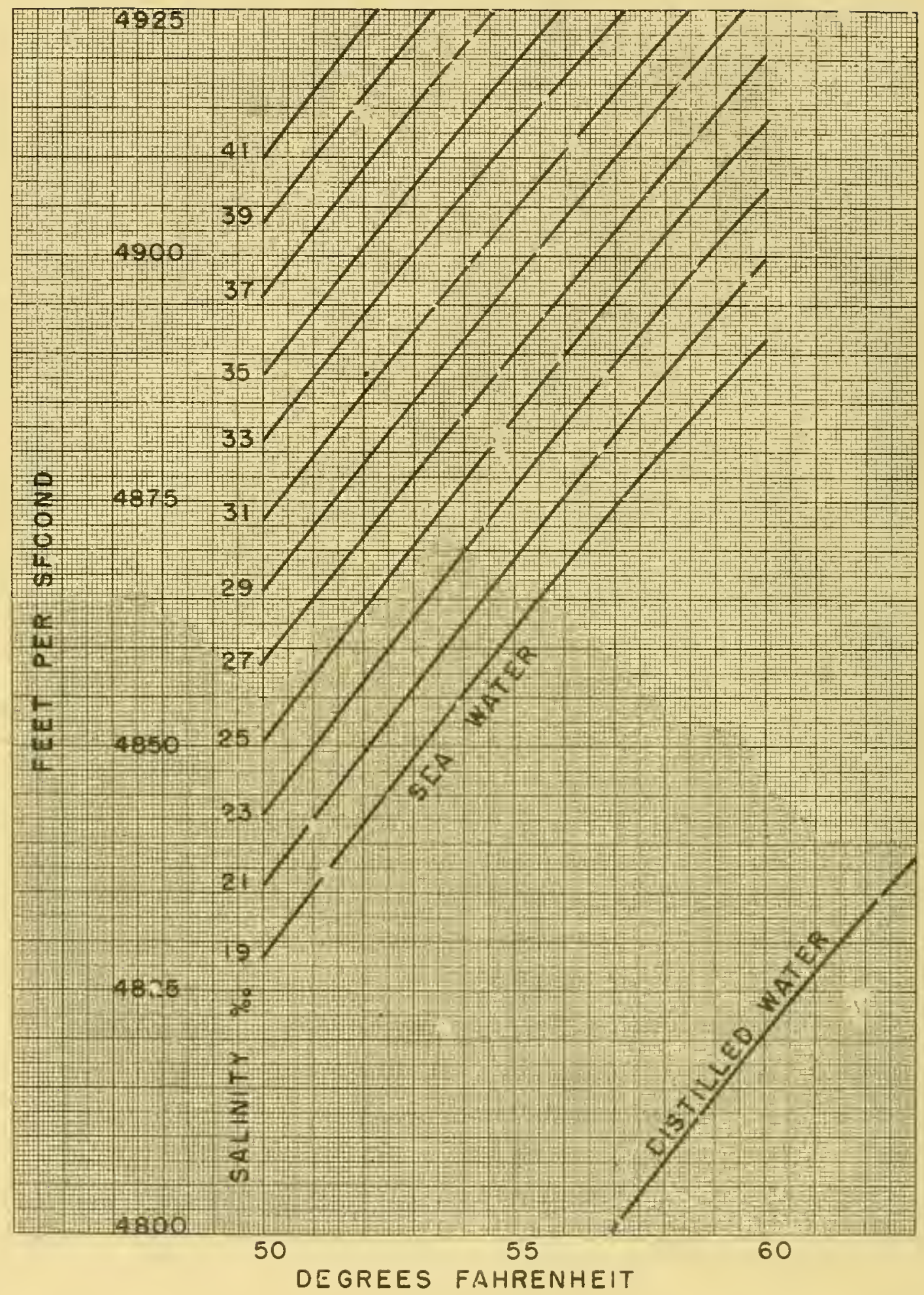

Figure 2-g 


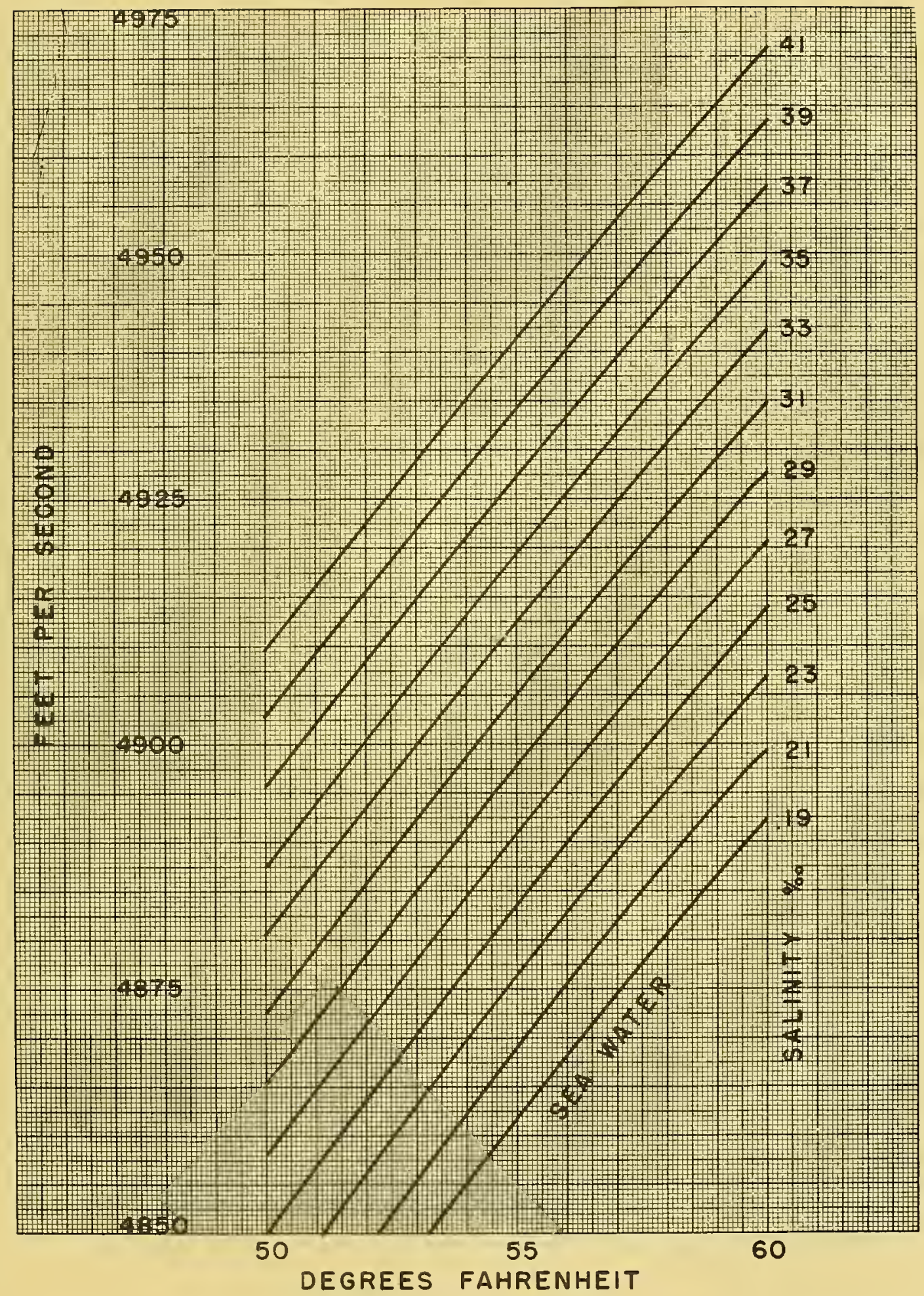

Figure 2-h 


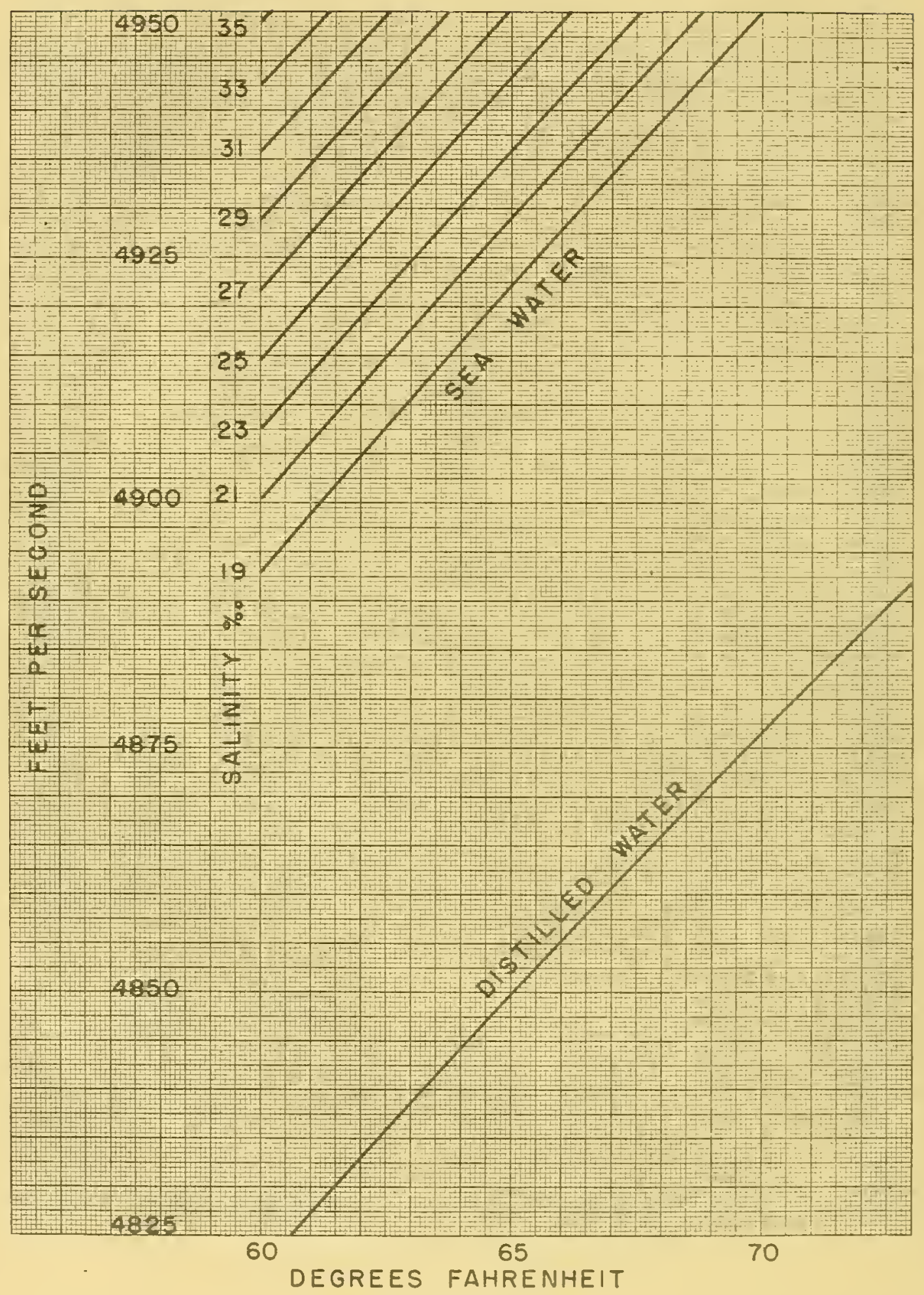

Figure 2-i 


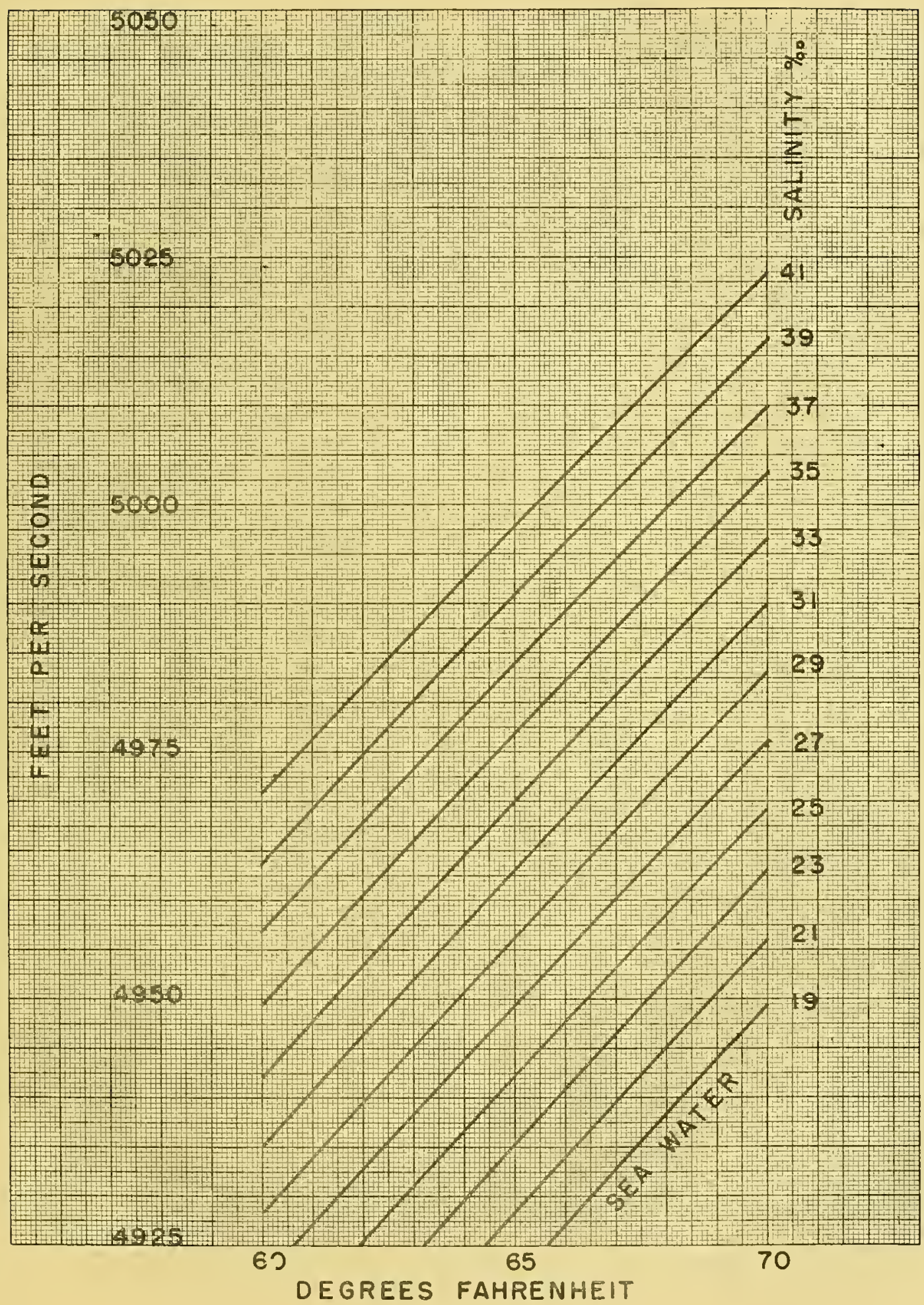

Figure 2-j 


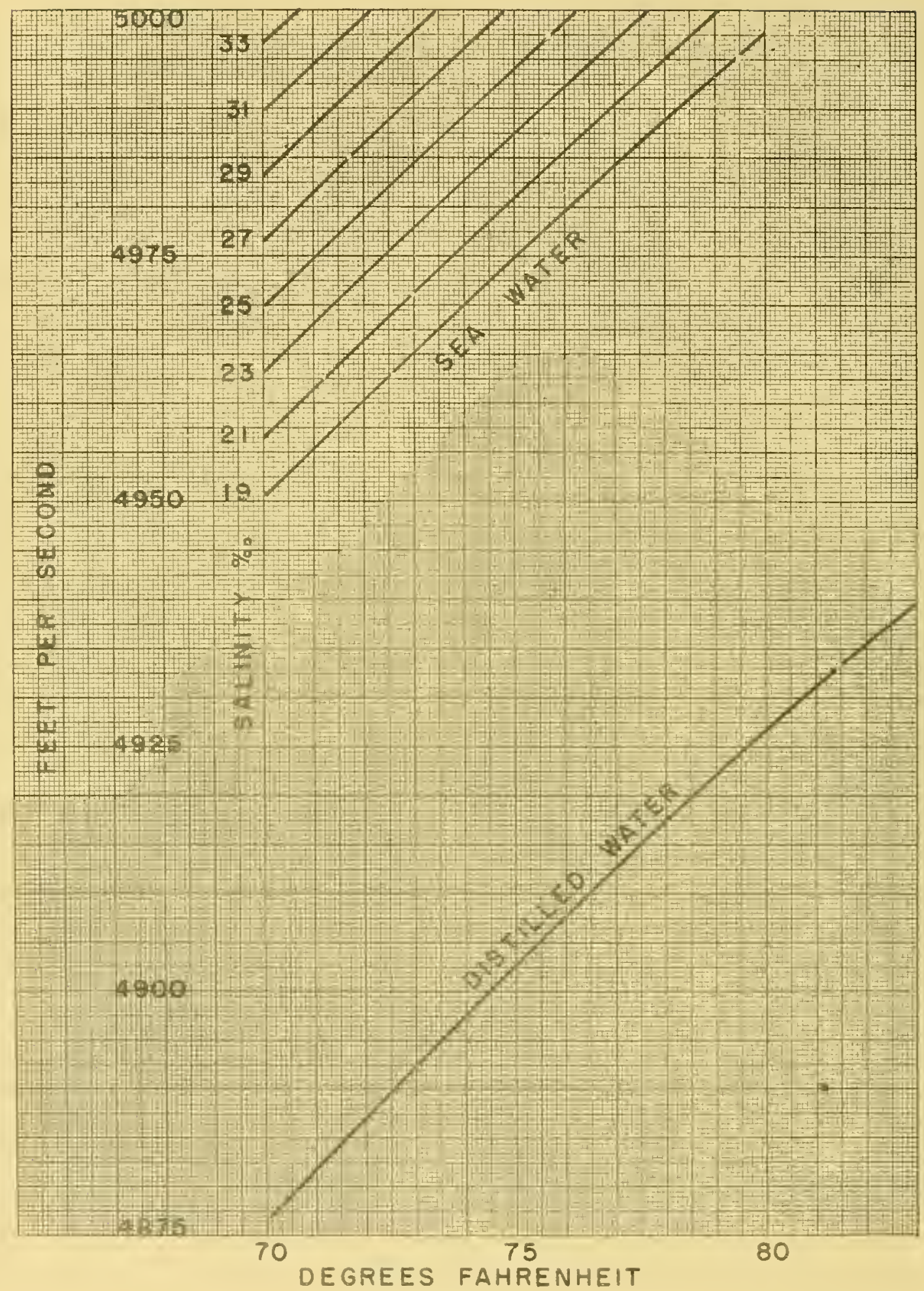

Figure 2-k 


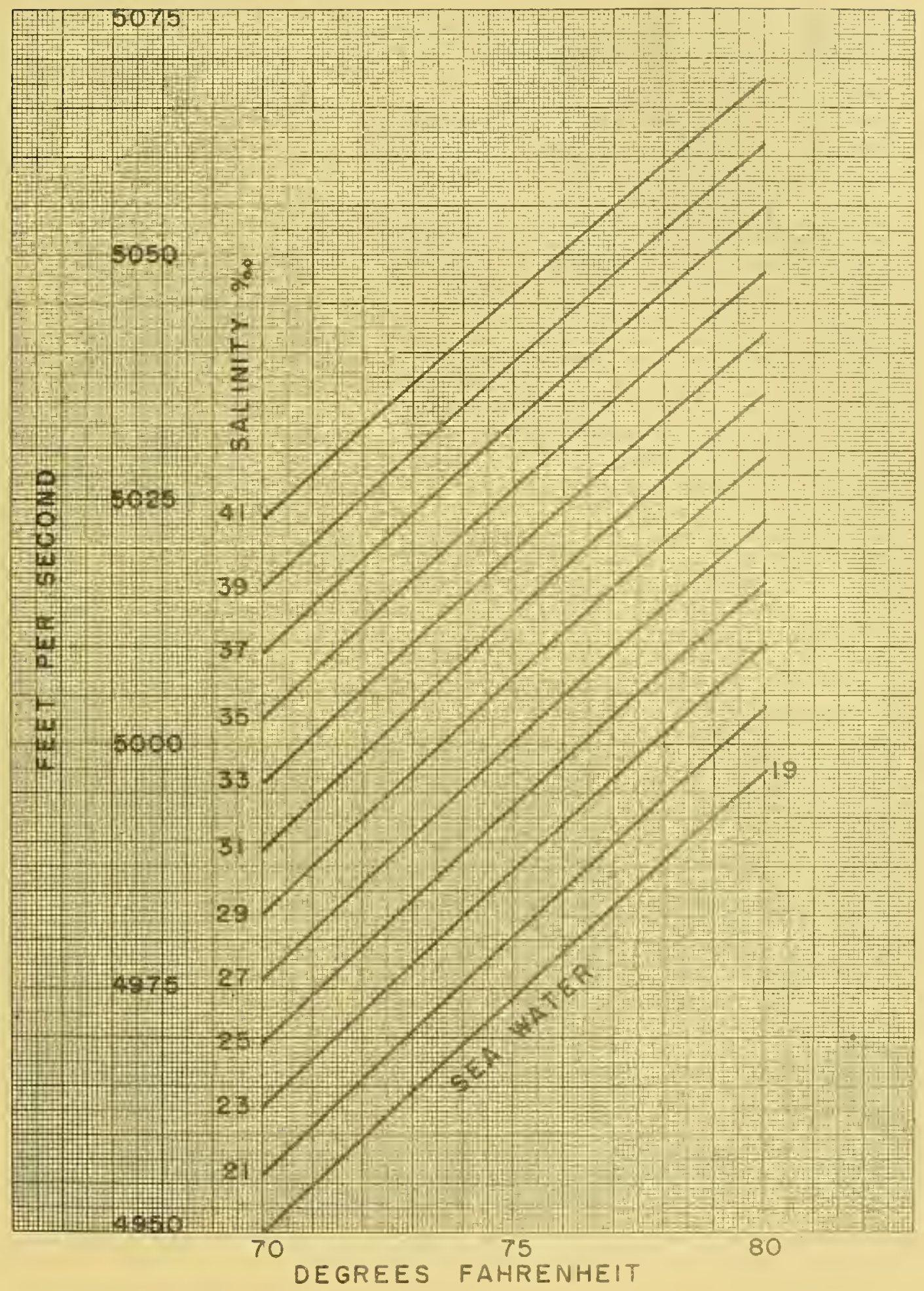

Figure 2-1 


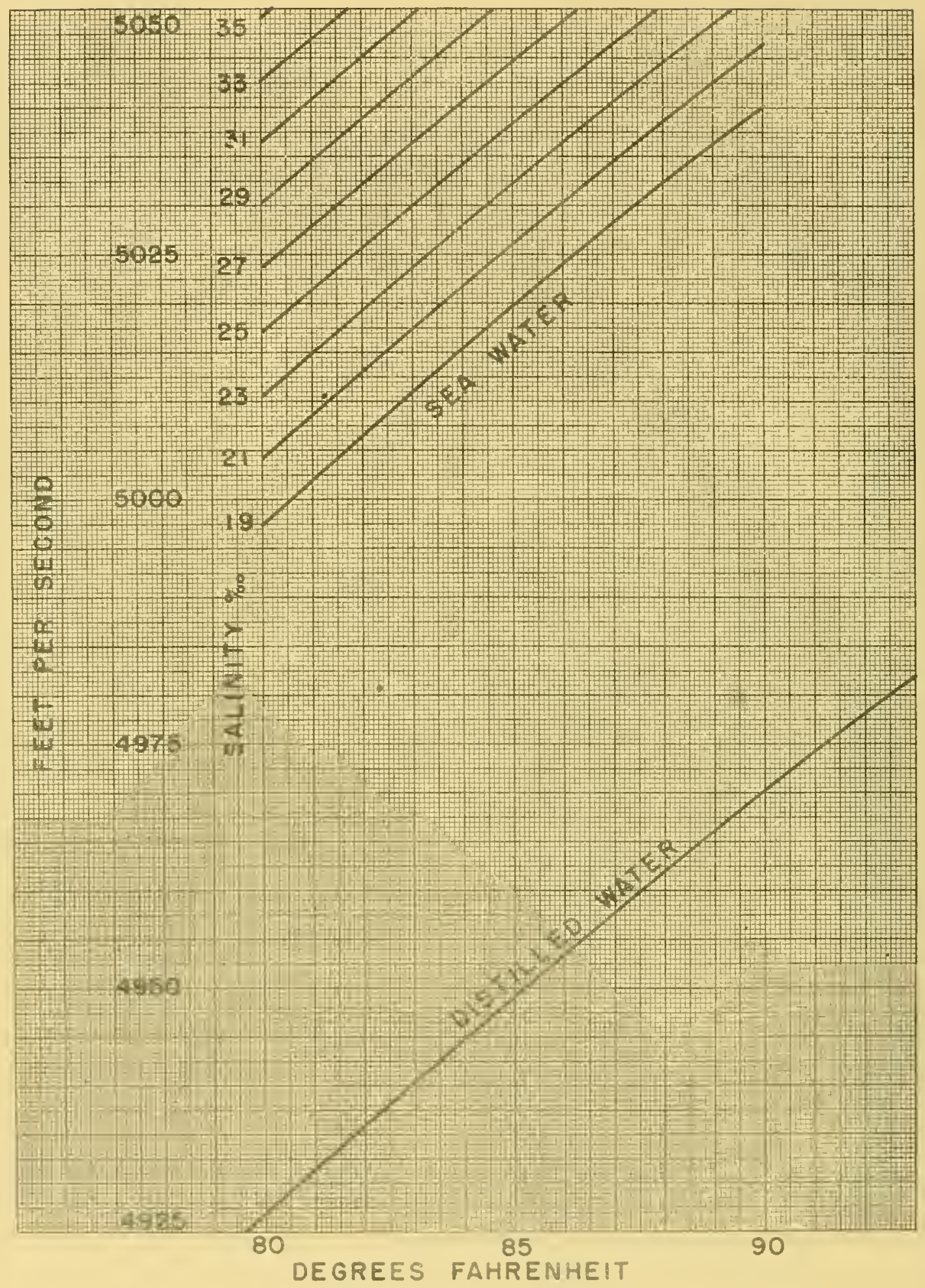

Figure 2-m 


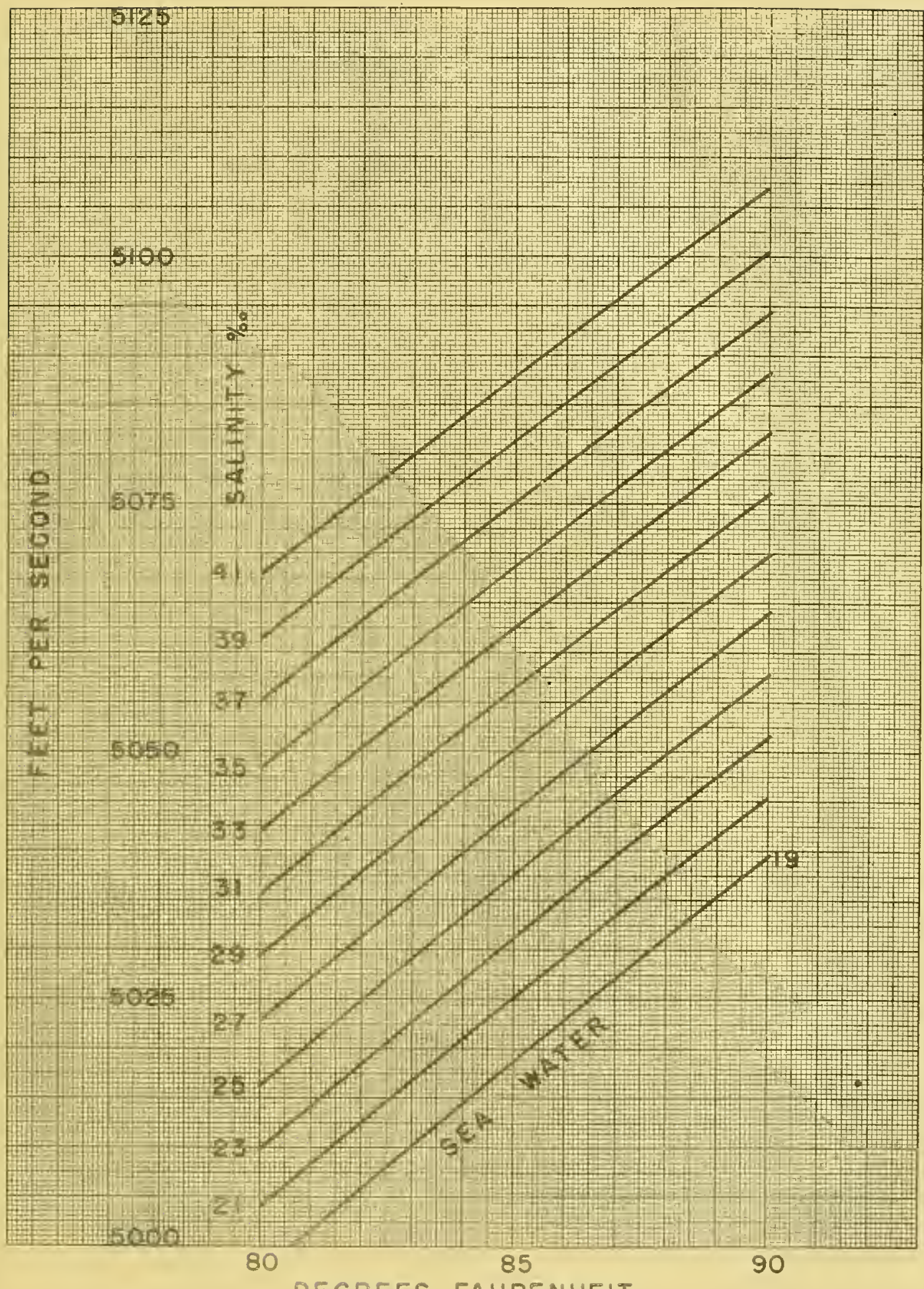

DEGREES FAHRENHEIT 


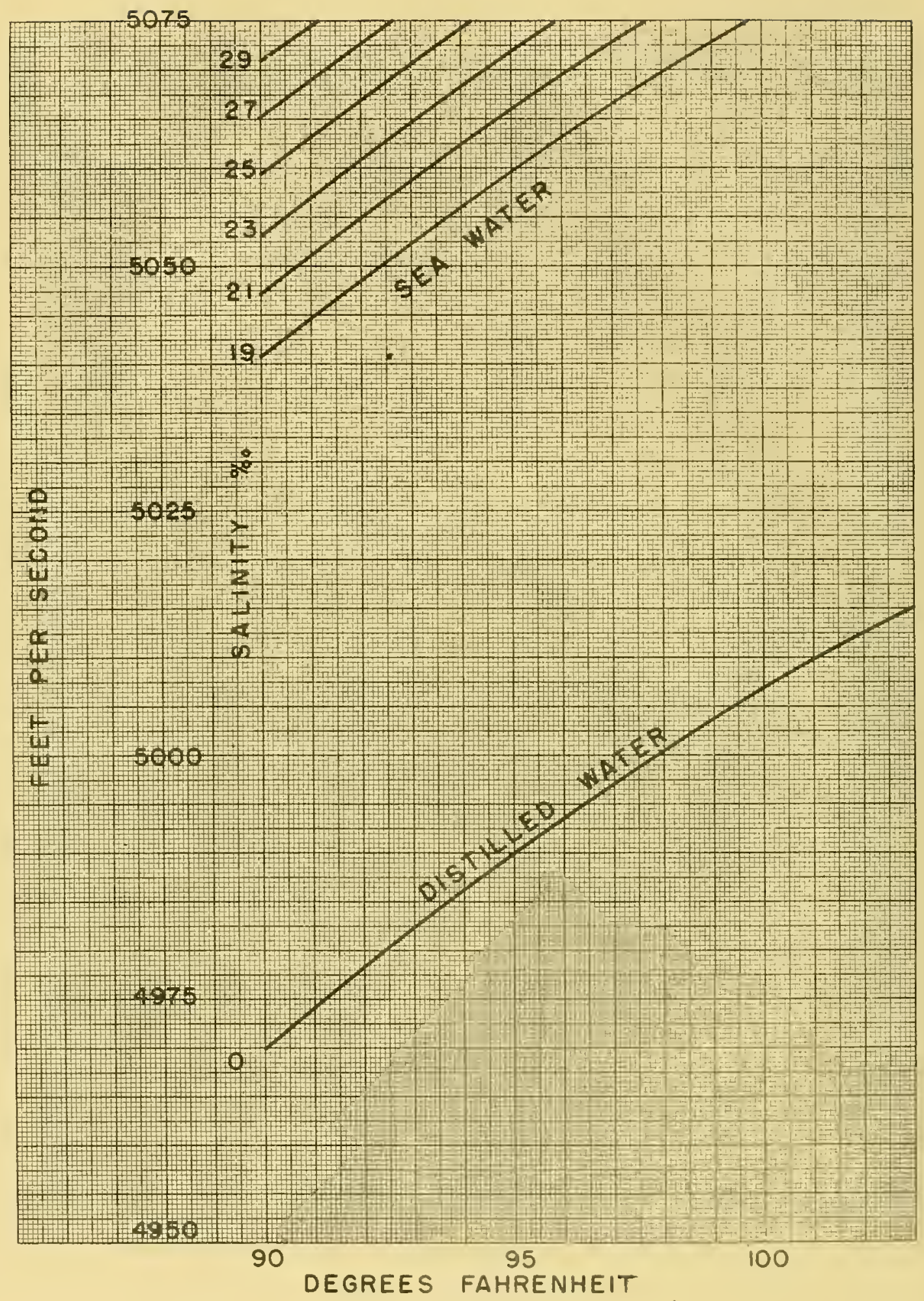

Figure 2-o 


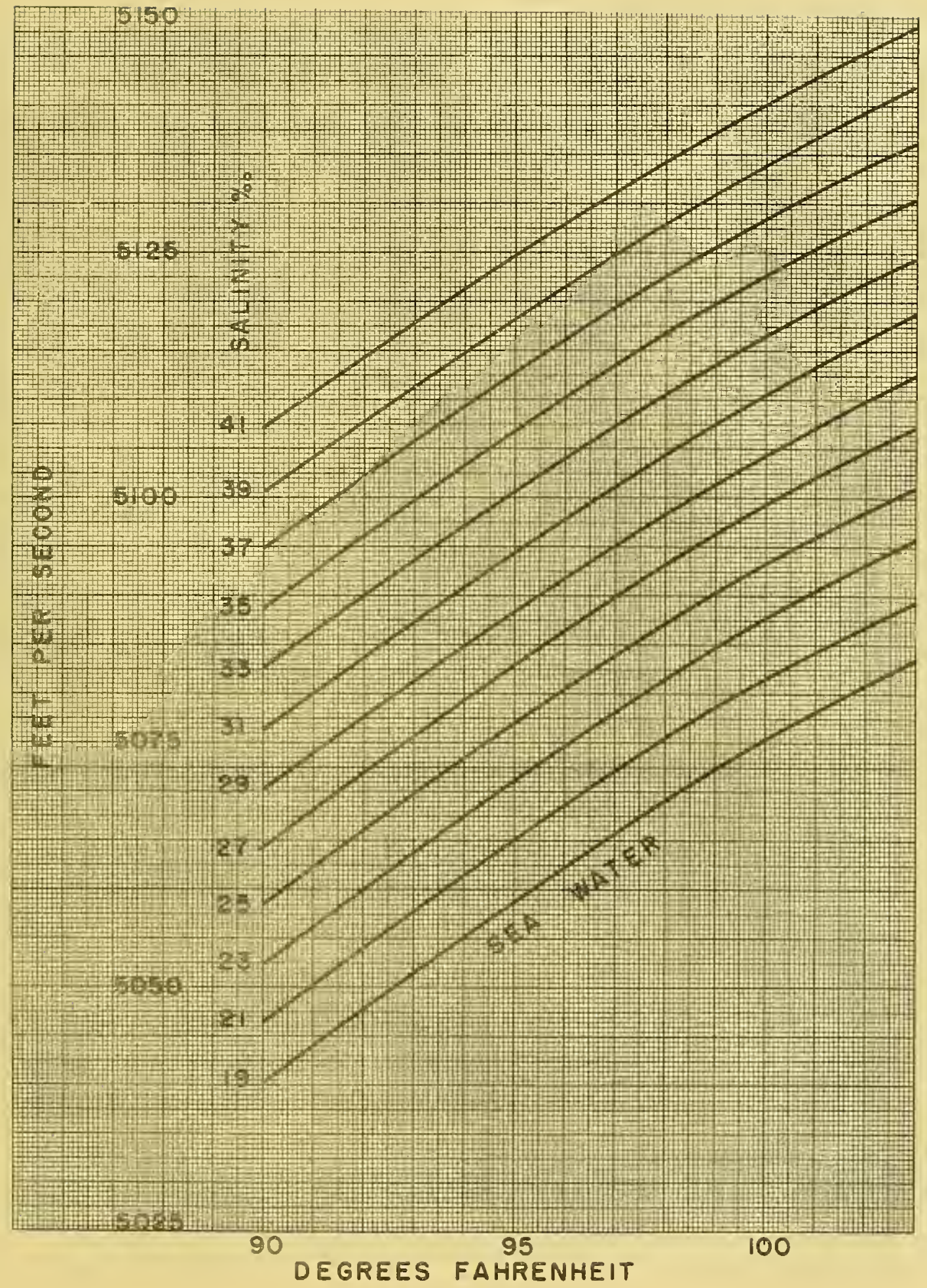

Figure 2-p 


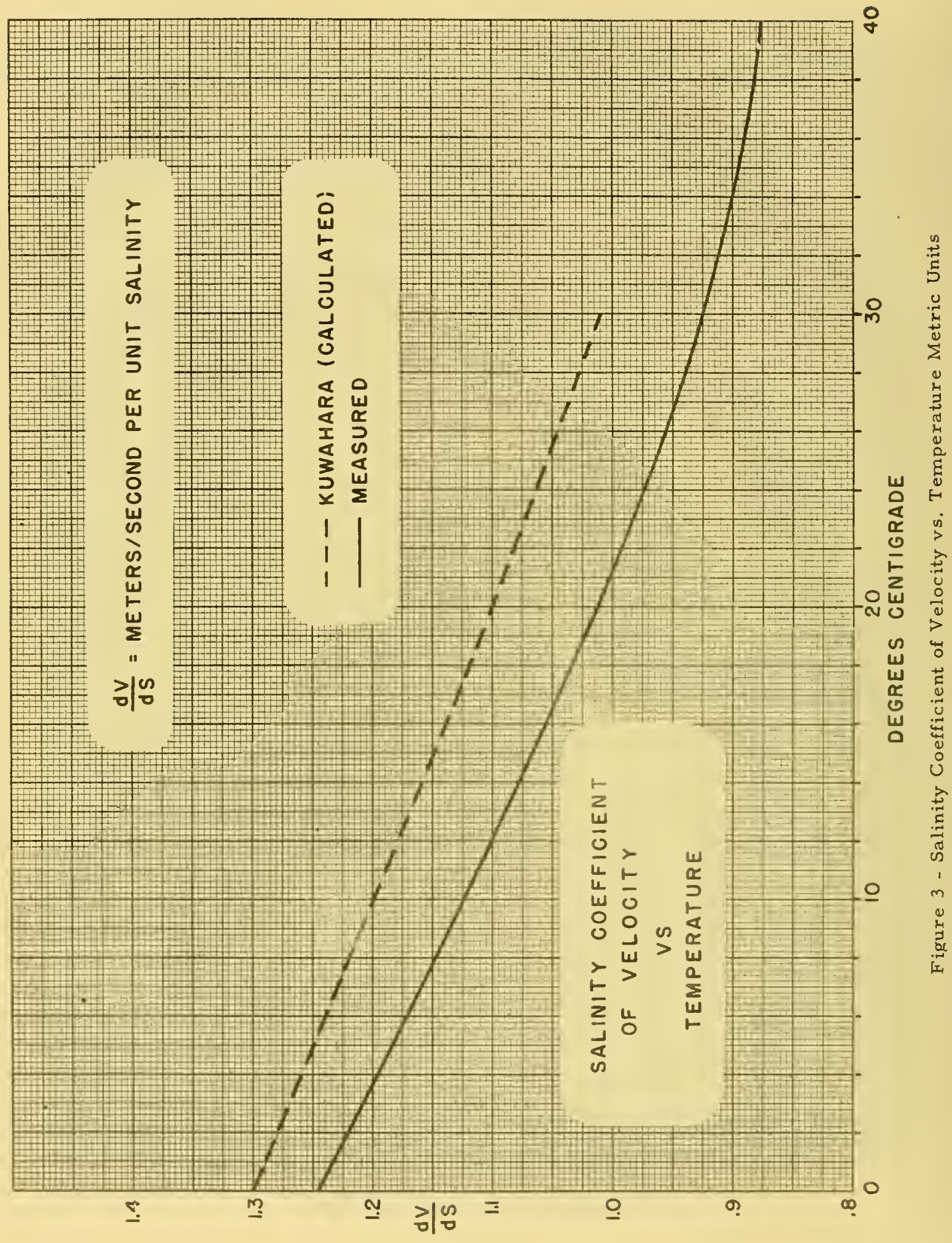




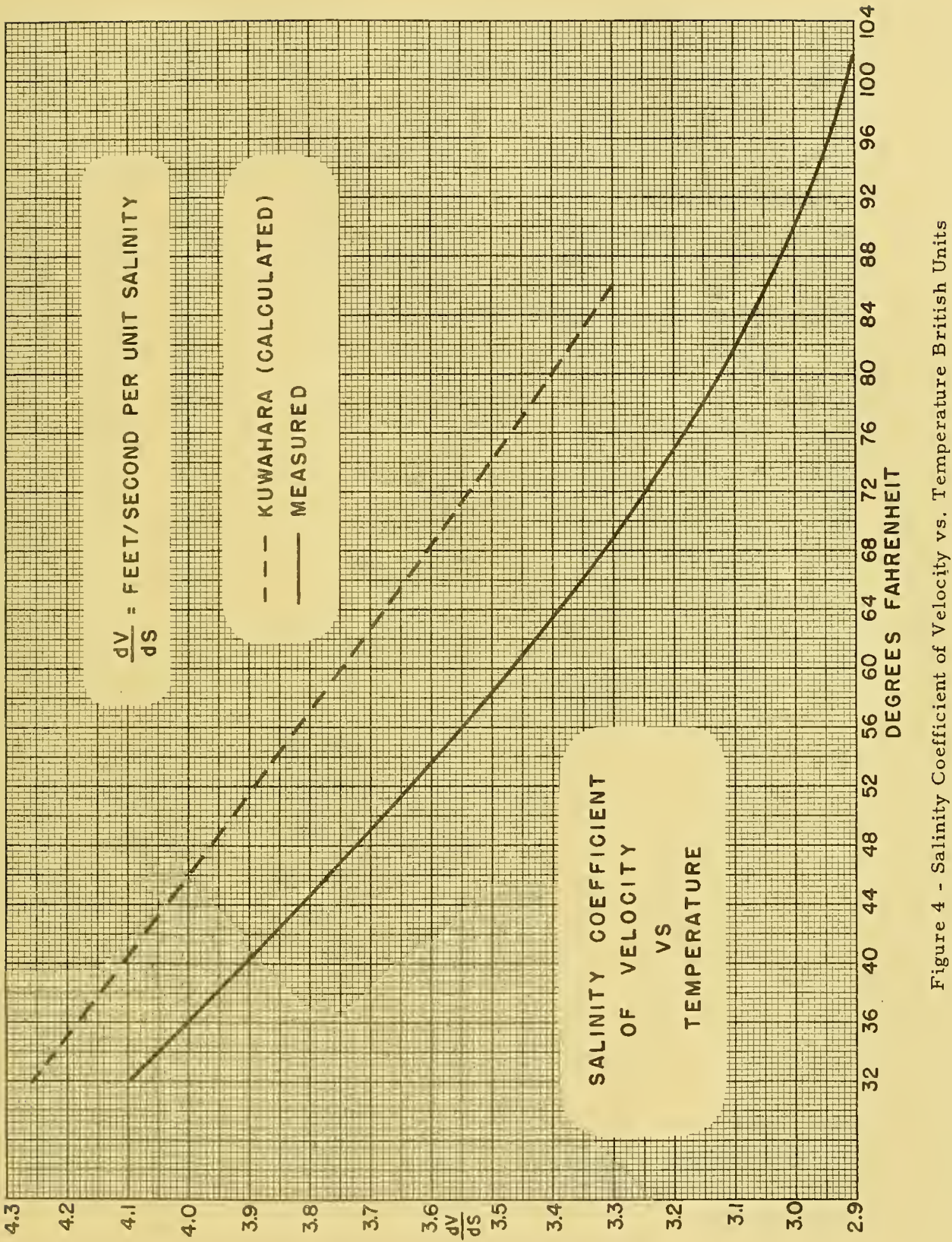



· 
